\title{
Potential of Mulberry Leaf Biomass and Its Flavonoids to Improve Production and Health in Ruminants: Mechanistic Insights and Prospects
}

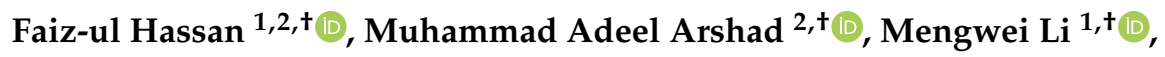 \\ Muhammad Saif-ur Rehman ${ }^{2}$, Juan J. Loor ${ }^{3}(1)$ and Jiaxiang Huang ${ }^{1, *}$ \\ 1 Key Laboratory of Buffalo Genetics, Breeding and Reproduction Technology, Ministry of Agriculture and \\ Guangxi Buffalo Research Institute, Chinese Academy of Agricultural Sciences, Nanning 530001, China; \\ f.hassan@uaf.edu.pk (F.H.); lmw1607@163.com (M.L.) \\ 2 Institute of Animal and Dairy Sciences, Faculty of Animal Husbandry, University of Agriculture, \\ Faisalabad 38040, Pakistan; adeel.2203@gmail.com (M.A.A.); shsaifurrehman@yahoo.com (M.S.R.) \\ 3 Department of Animal Sciences, Division of Nutritional Sciences, University of Illinois, \\ Urbana, IL 61801, USA; jloor@illinois.edu \\ * Correspondence: huangjx080@163.com; Tel.: +86-1580-771-1618 \\ + These authors contributed equally to this work.
}

Received: 14 October 2020; Accepted: 4 November 2020; Published: 9 November 2020

Simple Summary: The economics of livestock production depends upon the feasible feeding resources as feed costs constitute more than $70 \%$ of the total expenses of a livestock enterprise. In this regard, searching for alternative and cheaper feeding resources is imperative for economical and sustainable livestock production. Mulberry leaves are an important resource available for feeding livestock, as they possess quite high protein and energy contents as compared to other tree leaves and conventional forages. Moreover, polyphenolic compounds (mainly flavonoids) present in mulberry leaf (ML) possess excellent antioxidant and antimicrobial potential that can beneficially impact animal health and production. Mulberry leaves and its flavonoids have been shown to increase the feed digestibility and milk production in ruminants, while reducing methane emission. Moreover, mulberry flavonoids can positively influence body metabolism and alleviate oxidative stress in animals. This review highlights the importance of this unique feeding resource for ruminants to increase their performance while reducing methane emissions.

Abstract: Leaf biomass from the mulberry plant (genus Morus and family Moraceae) is considered a potential resource for livestock feeding. Mulberry leaves (MLs) contain high protein (14.0-34.2\%) and metabolizable energy (1130-2240 kcal/kg) with high dry matter (DM) digestibility (75-85\%) and palatability. Flavonoid contents of MLs confer unique antioxidant properties and can potentially help alleviate oxidative stress in animals during stressful periods, such as neonatal, weaning, and periparturient periods. In addition, mulberry leaf flavonoids (MLFs) possess antimicrobial properties and can effectively decrease the population of ruminal methanogens and protozoa to reduce enteric methane $\left(\mathrm{CH}_{4}\right)$ production. Owing to its rich flavonoid content, feeding MLs increases fiber digestion and utilization leading to enhanced milk production in ruminants. Dietary supplementation with MLFs alters ruminal fermentation kinetics by increasing total volatile fatty acids, propionate, and ammonia concentrations. Furthermore, they can substantially increase the population of specific cellulolytic bacteria in the rumen. Owing to their structural homology with steroid hormones, the MLFs can potentially modulate different metabolic pathways particularly those linked with energy homeostasis. This review aims to highlight the potential of ML and its flavonoids to modulate the ruminal microbiome, fermentation, and metabolic status to enhance productive performance and health in ruminants while reducing $\mathrm{CH}_{4}$ emission. 
Keywords: mulberry leaf biomass; flavonoids; antioxidant; rumen fermentation; methane mitigation; performance

\section{Introduction}

Appropriate and feasible feed resources are required to ensure sustainability of animal production and match ever-increasing global demand for animal products. Crop residues, agro-industrial by-products, shrubs, and tree foliage are usually considered alternate feeding resources for livestock, but their lower digestibility, poor nutritive value (low protein and energy), and unbalanced trace element contents limit more extensive application [1,2]. Inclusion of tropical trees and foliage in cattle ration decreases methane $\left(\mathrm{CH}_{4}\right)$ emission by 10-25\%, depending on plant species and level of intake of the ration [3]. Thus, efforts in tropical countries are usually focused on identifying and using local trees and shrubs for livestock feeding owing to their better nutritive value and positive effects on rumen physiology [4-6]. Leaf biomass of mulberry trees (family Moraceae and genus Morus) have been considered traditionally as an alternate livestock feeding resource in China because of their high nutritive profile and flavonoid contents [7]. The mulberry tree is native to the China/Japan area and in the Himalayan foothills but is now cultivated worldwide due to its ability to grow in diverse climates ranging from temperate to tropical areas. Approximately 80 species of genus Morus exist around the world; among them, four species viz M. albus, M. atropurpurea, M. multicaulis, and M. bombycis are mainly under cultivation [8,9]. Mostly M. albus and indica are utilized in livestock feeding; however, nowadays, paper mulberry (Broussonetia papyrifera) is also getting attention because of its antioxidant capacity [10].

Compared to many other traditional forages, mulberry leaves (MLs) contain relatively high protein content (14.0-34.2\%), have a high in vivo DM digestibility (75-85\%), and are highly palatable due to their succulent nature [11,12]. Protein content of ML is even greater than other traditional forages and is even better than soybean meal, considered a high-quality protein feed for livestock [13-15]. Several studies have evaluated the potential use of MLs as a feed ingredient (good quality protein source) in the diets of different livestock species including sheep [16], beef cattle [17], dairy calves [18], and pigs [19]. Fresh leaves are typically fed to animals but ensiled MLs have also shown potential for feeding of beef animals without adversely affecting growth performance and carcass quality $[20,21]$. The unique nutrient profile, digestibility, and palatability characteristics of MLs make them an excellent protein-rich forage for both monogastric and ruminant animals [22,23].

Owing to an excellent nutrient profile and bioactive components, MLs possess excellent potential as an ingredient in ruminant feed. Despite its nutrient and bioactive rich contents, ML biomass is not extensively utilized for livestock feeding. This review focuses on rich phytochemistry of ML biomass and provides mechanistic insights into the potential of mulberry leaf flavonoids (MLFs) to modulate the ruminal microbiome, fermentation, and antioxidant and metabolic status to enhance productive performance and health in ruminants. The primary objective is to stimulate interest in this natural resource for livestock feeding and encourage researchers to explore the molecular mechanism underlying the biological activities of MLFs.

\section{Plant Secondary Metabolites of Mulberry Leaf Biomass}

Besides their high protein and energy content, MLs also contains a wealth of plant secondary metabolites, especially flavonoids. It is well established that plant secondary metabolites such as tannins, saponins, flavonoids, glucosinolates, mimosine, and essential oils possess different properties including antimicrobial, antioxidant, and anti-inflammatory [24,25]. Among plant secondary metabolites, flavonoids are known as benzo-l-pyrone that have anti-inflammatory, antioxidant, and antimicrobial properties [26,27]. Flavonoids from MLs are famous for their antioxidant potential. Owing to their excellent antioxidant activities, MLFs are of great importance from a biological and pharmacological 
perspective. Numerous studies have confirmed the antioxidant capacity of MLs or their extracts in rats, cattle, and sheep $[18,28,29]$. The most promising activities of flavonoids, in addition to being antioxidants, pertain to their potential to modulate different metabolic pathways, especially those linked with energy homeostasis in the body. Due to structural homology with estrogenic hormones, flavonoids exhibit similar anabolic functions through modulation of key lipid and carbohydrate metabolic pathways. Mulberry leaf extract has shown to upregulate the activities of glycolytic enzymes through modulation of gene and transcription factors involved in glucose homeostasis in the liver [29-31].

Mulberry leaf flavonoids also exert desirable effects on ruminal function to sustain health and performance [32,33]. Flavonoids alter rumen fermentation dynamics (increased propionate proportion) and favor growth of beneficial microbes like M. elsdenii (lactate-utilizing bacteria), which might have desirable effect on animal performance [34]. Mulberry leaf polysaccharides are bioactive components with desirable effects on metabolism and immunity [35].

Supplementation of mulberry leaf powder (MLP) and puerariae flavone in lambs and rams, respectively, improved liver activity by decreasing plasma concentrations of alanine aminotransferase (ALT), aspartate aminotransferase (AST), and lactate dehydrogenase (LD) levels [36,37]. High concentrations of these metabolites in serum are associated with liver and cardiovascular disorders such as Kupffer cell reduction [38,39]. Kupffer cells known as first innate immune cells that have a critical role in maintaining liver functions and protecting the liver from bacterial infections [40]. Some plant secondary metabolites have anti-nutritional factors that can adversely affect health of calves and monogastric animals. However, at an appropriate level, many of them beneficially affect the host metabolism and performance.

\section{Mulberry Tree Cultivation, Global Distribution, and Leaf Biomass Yield}

The mulberry tree has a broader geological distribution (temperate, tropical, subtropical, and arid regions) in different forms (bush, dwarf, and tree). It is being cultivated in different countries of Asia and Europe (from Korea to Spain, France, Italy, Turkey, China, Pakistan, India, Afghanistan, Central Asia, and the Near East); in Africa (North and East Africa, Kenya, and Tanzania); and the Americas (from the United States to Argentina, including Mexico, Central America, Colombia, Peru, and Brazil) (Figure 1). Mulberry can grow in different agro-climatic conditions, such as mountains, plains, irrigated as well as in harsh conditions of humid and semi-arid lands $[41,42]$. The average yield of leaf and stem biomass as forage ranges from 8 to 52 tons/hectare/year $[43,44]$. This huge variation in biomass yield is attributed to different mulberry species, agro-climatic conditions, geographical location, soil type, and harvesting method. The most common species of mulberry (Morus alba and indica) can yield a leaf biomass of approximately 25 to 30 tones/ha/year with a shorter harvesting interval of about 9 to 10 weeks, owing to its ease of propagation and excellent growth characteristics [9]. It makes mulberry a suitable forage for livestock that can be used for feeding fresh or can be processed by making silage to be used for longer periods particularly during the period of fodder shortage.

Most commonly, leaves of the mulberry tree are being used in sericulture for the feeding of silkworm, which is an established industry. Various parts of mulberry (leaf, stem, and root) are utilized in the preparation of various products in pharmaceutical, food, cosmetic, and health care industries $[45,46]$. From a phytopharmaceutical point of view, the extract of mulberry is utilized as a source of various compound such as carotenoids, coumarins, arylbenzofuran, $\gamma$-aminobutyric acid, cyanidin-3-O-beta-D glucopyranoside, 1-deoxynojirimycin, ethyl acetate, flavonoids, moran, moranolin, polyphenols, pyrrole alkaloids, polyhydroxy alkaloids, and vitamins [42,47]. Mulberry also has tremendous potential in improving human health owing to its diverse biologically activities including anti-allergic, anti-aging, anti-atherogenic, anti-bacterial, anti-cancer, anti-hypertensive, anti-inflammatory, anti-obesity, anti-oxidant, anti-schistosomal, anti-viral, cardiovascular protectant, free radical scavenging, hepatoprotective, hypoglycemic, lipid-lowering, macrophage activating, neuroprotective, vasoactive, and disinfectant properties [42,48]. 


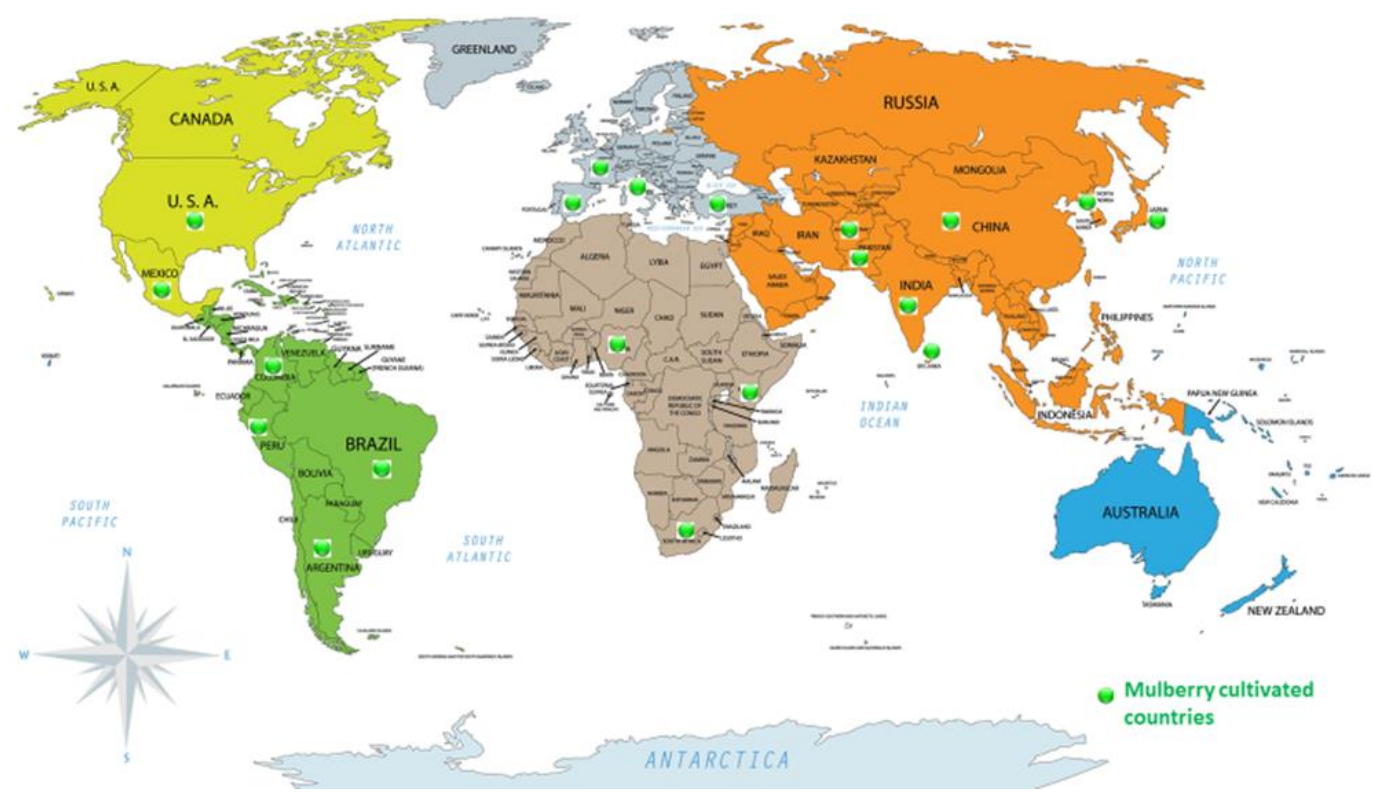

Figure 1. Worldwide distribution of mulberry cultivation.

\section{Nutritional Profile of Mulberry Leaves}

Alfalfa and berseem are most commonly utilized forages in ruminant diet due to their higher protein (approximately 18-20\%) content. Compared with other green leafy vegetables, MLs generally possess greater protein content [49]. Therefore, MLs can be used as an alternate animal feed ingredient to replace plant-based protein sources, due to its high protein content, metabolizable energy (1130-2240 kcal/kg), and digestibility $[9,15,50-52]$. Despite the fact that mulberry is not a legume crop, its leaves still possess a considerable amount of different nutrients, especially protein (14.0-34.2\%), carbohydrates (9.7-39.7\%), and neutral detergent fiber (19.4-49.7\%) on a DM basis (Table 1). The MLs have excellent palatability compared to other fodders (Leucaena and Moringa) as well as high in vitro $(>80 \%)$ and in vivo $(>78 \%)$ digestibility in small ruminants $[12,53]$. Ensiled MLs possess good amounts of crude protein $(19.8 \%)$, water-soluble carbohydrates $(15.6 \%)$, and neutral detergent fiber $(51.5 \%)$, along with trace elements [20].

Notably, MLs also contain different macro minerals (calcium, magnesium, potassium, and phosphorus) and micronutrients such as vitamin C, D, and B1, beta-carotene, iron, and zinc [54,55]. Further, MLs also possess various bioactive compounds (phenolic acids, flavonoids, alkaloids, and $\gamma$-aminobutyric acid) with antioxidant and anti-inflammatory function [56,57]. Major antioxidant compounds such as chlorogenic acid, isoquercitrin, and astragalin are also present in MLs [58]. Indeed, MLs also contain a considerable amount of primary fatty acids such as palmitic (26.38\% and $25.99 \%)$, $\alpha$-linolenic (34.97\% and 37.57\%), and linoleic acid (14.76\% and 16.05\%) [59].

Table 1. Chemical composition of mulberry leaves (\%).

\begin{tabular}{ccccc}
\hline Nutrient & Range & Average $^{+}$ & SEM $^{*}$ & References \\
\hline Dry matter & 18 to 30.5 & 27.3 & 1.61 & {$[6,21,51,55,60-65]$} \\
Crude protein & 14 to 34.2 & 21.4 & 0.88 & {$[6,21,50,51,55,58,60-74]$} \\
Organic matter & 86.4 to 89.8 & 87.9 & 0.72 & {$[21,51,61,70]$} \\
Fat & 3.5 to 8.1 & 5.1 & 0.46 & {$[50,51,55,60,61,64,65,67-74]$} \\
Fiber & 5.4 to 38.4 & 16.4 & 2.83 & {$[50,51,55,58,60,61,66-68,70]$} \\
NFE & 25 to 47.9 & 40.1 & 5.11 & {$[50,61,67,70]$} \\
NDF & 19.4 to 49.7 & 32.6 & 1.72 & {$[6,21,50,51,55,58,63-65,68-74]$} \\
ADF & 10.2 to 31.8 & 40.1 & 1.46 & {$[6,21,51,58,62,64-66,72,73]$} \\
Ash & 7.6 to 22.4 & 13.1 & 0.85 & {$[50,55,60-64,66,67,71-74]$} \\
\hline
\end{tabular}

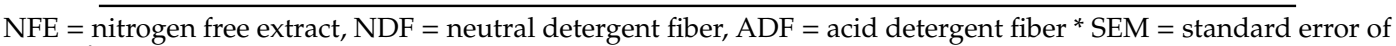
mean, ${ }^{\dagger}$ calculated as described by St-Pierre [75]. 


\section{Anti-Nutritional Factors in Mulberry Leaves}

Mulberry leaves contain different antinutritional factors, including oxalates ( $183 \mathrm{mg} / 100 \mathrm{~g})$, cyanide $(1.01-2.14 \mathrm{mg} / \mathrm{kg})$, tannins $(5.32-5.78 \mathrm{mg} / \mathrm{kg})$, and phytate $(451-488 \mathrm{mg} / \mathrm{kg})$ on a DM basis $[60,76]$. Nevertheless, tannins are not considered as an adverse antinutritional factor in ruminants, as they impart some desirable effects such as decreasing protein degradability in rumen coupled with inhibition of methanogenesis and fatty acid biohydrogenation [77,78]. Moreover, MLs also contain iminosugar alkaloids, which can exert an inhibitory effect on mammalian glucosidase enzymes. It is also reported to contain a polyhydroxylated piperidine alkaloid, 1-deoxynojirimycin $(0.131-3.483 \mathrm{mg} / \mathrm{g})$, which is a promising competitive inhibitor of intestinal $\alpha$-glucosidases [79-82]. Feeding oxalate at $6.75 \mathrm{~g} / \mathrm{head} / \mathrm{d}$ reduced feed intake in goat [83]. Similarly, Rahman et al. [84] showed that feeding oxalate at $30 \mathrm{~g} / \mathrm{kg}$ DM decreased Ca bioavailability in sheep. Non-ruminants are more sensitive to oxalate than ruminants, as oxalate is degraded by ruminal bacteria. According to Rahman et al. [85], provision of soluble oxalate less than $2 \%$ is an appropriate level to avoid oxalate poisoning, although blood Ca level may decrease in ruminants. Provision of potassium cyanide at $3.8 \mathrm{mg} / \mathrm{kg} / \mathrm{d}$ in goats had an adverse effect on the nervous system [86]. Studies reporting the effect of these antinutritional factors of MLs in ruminants are lacking, so future investigations are required in this regard.

\section{Structure, Bioavailability, and Absorption of Mulberry Leaf Flavonoids}

\subsection{Structure of Mulberry Leaf Flavonoids}

Flavonoids belong to a diverse class of plant compounds that are grouped according to their basic structure: flavonols, flavones, anthocyanins, flavanols, flavanones, and isoflavones [87]. The predominant flavonoids in MLs are flavonols that possess malonyl, acetyl, or other groups as terminal sugars in their basic skeleton $[88,89]$. Such modifications in the basic skeleton of flavonoids result in the yield of a considerable number of end products with diverse bioactivities. For example, mono- and di-O-glycosylated flavonols are the most abundant flavonoids in MLs, which usually include isoquercitrin, astragalin, kaempferol, quercetin 3-(6-acetylglucoside), and rutin with potential anti-inflammatory properties [90,91].

Flavonoids present in mulberry naturally occur in three forms including aglycones, glycosides, and methylated derivatives (Figure 2). The basic structure of flavonoids is aglycone in which the 6-carbon ring is condensed with benzene to make $\alpha$-pyrone (flavonols and flavanones) or its dihydro derivatives (flavonols and flavanones). The presence of the benzene ring classifies them as flavonoids (at 2-position) or isoflavonoids (at 3-position). Flavonols differ from flavanones by the hydroxyl group at the 3-position and a C2-C3 double bond [92]. Most flavonoids (except catechin) are present in bound form (glycosides), in which aglycone is attached with a sugar (L-rhamnose, D-glucose, glucorhamnose, galactose, or arabinose) through a $b$-glycosidic bond at position 3 of the $C$ ring $[93,94]$. Flavonoids in free form (aglycans) can be easily absorbed through the small intestine, but their conjugated forms (flavonoid glycosides) require a first conversion into aglycon before absorption [95]. The presence of a sugar moiety not only determines bioavailability but also reduces its functional properties. Comparison of intraduodenal administration of quercetin in its free aglycone or glucorhamnoside form in Holstein cows revealed greater intestinal bioavailability of free quercetin (aglycone form) as compared to the glycosidic form (glucorhamnoside) [96]. 
<smiles>BrC(Br)(Br)c1ccccc1C1CCc2ccccc2O1</smiles>

Flavonol<smiles>O=c1c(O)c(-c2ccccc2)oc2ccccc12</smiles>

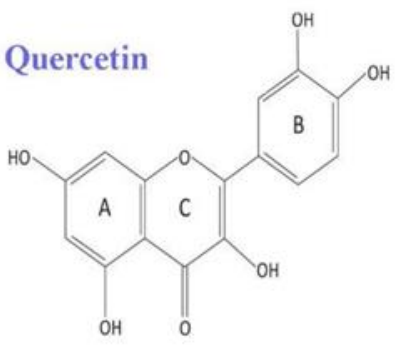<smiles>O=c1cc(-c2ccccc2)oc2ccccc12</smiles>

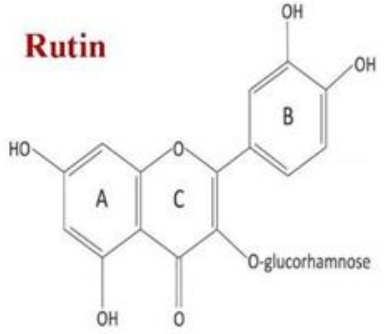

Figure 2. Basic structure of flavonoids present in mulberry leaves.

\subsection{Flavonoid Contents of Mulberry Leaf and Their Bioactivities}

The average contents of major flavonoids present in MLs are shown in Table 2. Studies have reported variable contents of total and specific flavonoids in ML, some of which may be attributed to different cultivars of mulberry. Mulberry leaves contain a considerable amount of quercetin (particularly quercetin 3-(6-malonylglucoside), even greater than onions, and is responsible for the potent antioxidant effects of MLs detected under in vitro and in vivo conditions. Furthermore, ML contains other vital flavonoids such as 1-deoxynojirimycin (DNJ), resveratrol, Oxyresveratrol, Cyanidin 3-O- $\beta$ glucoside, and Cyanidin 3-O- $\beta$ rutinoside $[97,98]$.

Table 2. Flavonoid and phenolic contents (mg/g) in mulberry leaf biomass.

\begin{tabular}{cccccccc}
\hline Total Flavonoids & Rutin & CHA & IQT & QMG & AG & KMG & References \\
\hline $21.36-56.41$ & $0.42-4.31$ & $2.45-10.24$ & $0.70-4.83$ & $0.68-3.05$ & $0.30-1.32$ & $0.46-1.19$ & {$[58]$} \\
ND & 0.90 & ND & ND & 0.47 & ND & 0.19 & {$[54]$} \\
$24.34-58.42$ & $1.09-8.35$ & $4.10-9.67$ & ND & $0.36-13.92$ & ND & $0.07-3.21$ & {$[99]$} \\
$9.84-26.6$ & ND & ND & ND & ND & ND & ND & {$[100]$} \\
$22.5-33.3$ & 2.1 & $0.13-0.27$ & $3.70-4.01$ & ND & ND & ND & {$[59]$} \\
\hline
\end{tabular}

$\mathrm{CHA}=$ chlorogenic acid, $\mathrm{IQT}=$ isoquercitrin, $\mathrm{QMG}=$ quercetin-malonylglucoside, $\mathrm{AG}=$ astragalin, KMG = kaempferol-malonyl-glucoside, $\mathrm{ND}=$ not determined. 
Plant flavonoids are very diverse in their chemical structures and are ubiquitously present in plants species particularly those used for livestock feeding. Quercetin is the most extensively investigated bioactive flavonoid with important antioxidant, anti-inflammatory, and metabolic potential [101,102]. Quercetin and its derivatives have shown effective hypoglycemic activity through alleviating hepatic oxidative stress [103]. Seven new flavonoids were identified in Korean mulberry (Morus alba L.) leaves including kaempferol and quercetin derivatives [88]. Although many studies have characterized flavonoid content, very few reports are available on flavones as compared to flavonols, despite the fact that apigenin and luteolin have also been identified in MLs. Isoflavones possess estrogenic properties and serve as regulators of expression of different genes and transcription factors and antioxidants but also have role in protein tyrosine kinase inhibitors [104]. The largest group of flavonoids is the flavones, which possess diverse biological functions and help plants resist various biotic and abiotic stresses (Table 3). Flavones have shown a positive impact on liver activity by decreasing plasma ALT, AST, and LD levels and also possess antifungal, antiviral, and antibacterial properties $[36,105]$. Although recent studies have reported flavone content in different mulberry varieties [106], detailed composition of flavonoids in various mulberry cultivars still needs to be investigated further [107].

Table 3. Biological activities of major flavonoids present in mulberry leaf biomass.

\begin{tabular}{|c|c|c|c|}
\hline Flavonoid & Mechanism & Major Activities & Reference \\
\hline Quercetin & $\begin{array}{l}\text { Inhibition of xanthine oxidase and } \\
\text { lipoxygenase, potential ROS } \\
\text { scavenger, DPPH scavenging activity, } \\
\text { radical oxygen absorption activity }\end{array}$ & Antioxidant & [108-110] \\
\hline Rutin & $\begin{array}{c}\text { DPPH radical scavenging activity, } \\
\text { Reducing ROS generation in } \\
\mathrm{H}_{2} \mathrm{O}_{2} \text {-treated APPswe cells }\end{array}$ & $\begin{array}{l}\text { Inhibition of lipid peroxidation } \\
\text { and act as an antioxidant, } \\
\text { revert the } \beta \text {-amyloid toxicity }\end{array}$ & {$[111,112]$} \\
\hline Kaempferol & $\begin{array}{l}\text { Improve glucose uptake of 3T3-L1 } \\
\text { adipocytes acting as partial agonists } \\
\text { of PPAR } \gamma \text {, superoxide anion radical } \\
\text { scavenging activity }\end{array}$ & $\begin{array}{l}\text { Ameliorate hyperglycemia, } \\
\text { antioxidant effects }\end{array}$ & {$[113,114]$} \\
\hline Isoquercitrin & $\begin{array}{l}\text { Lipid-lowering effect and reduced } \\
\text { ROS within the Hepatocytes }\end{array}$ & Reduce oxidative stress & {$[115,116]$} \\
\hline Apigenin & $\begin{array}{l}\text { Scavenging ROS and regulation of } \\
\text { Fas/FasL pathway }\end{array}$ & $\begin{array}{l}\text { Protects from toxicity and } \\
\text { hepatic necrosis }\end{array}$ & {$[117,118]$} \\
\hline Luteolin & $\begin{array}{l}\text { Scavenging reactive oxygen and } \\
\text { nitrogen species, inhibiting nuclear } \\
\text { factor-kappa B activity and } \\
\text { Activator protein } 1\end{array}$ & $\begin{array}{c}\text { Antioxidant and } \\
\text { anti-inflammatory activity }\end{array}$ & [119-121] \\
\hline Astragalin & $\begin{array}{c}\text { Suppression of } \\
\text { 6-hydroxydopamine-stimulated } \\
\text { neurotoxicity, decreased expression of } \\
\text { MDA, TNF- } \alpha \text {, IL-6, ROS }\end{array}$ & $\begin{array}{l}\text { Alleviation of oxidative stress, } \\
\text { cardioprotective Activity }\end{array}$ & {$[122,123]$} \\
\hline
\end{tabular}

\subsection{Ruminal Degradation, Absorption, and Bioavailability of Mulberry Flavonoids}

Generally, flavonoids are absorbed as monomeric form in small intestine of both monogastric species and preruminant calves. However, rumen microbial activity has a positive effect on the utilization of polymeric flavonoids [124]. Removal of the sugar group from aglycone is required to improve bioavailability of flavonoids in the gut. Studies have shown that ruminal microbes can break the $b$-glycosidic bond of rutin (quercetin3-O-rutinoside) leading to the release of quercetin and 
effectively enhancing its bioavailability in the gastrointestinal tract [125]. Furthermore, quercetin along with its methylated (isorhamnetin, tamarixetin) and dehydroxylated (kaempferol) derivatives have been detected in the systemic circulation of non-lactating cows [126], indicating a role of rumen microbes in flavonoid metabolism (Figure 3). Studies on the bioavailability of quercetin in ruminants are limited [96,125]; however, extensive reports are available in monogastric animals $[7,127,128]$. Intra-ruminal administration of aglycone or rutin revealed a lower absolute bioavailability of quercetin [125]. Nevertheless, similar plasma concentrations of quercetin have been observed after application of the equimolar amount of rutin and free quercetin (aglycone) in monogastric species [127]. Compared with quercetin aglycone, rutin proved to be a much better source of quercetin when administered intraruminally [125]. In contrast, intraduodenal administration of both forms of quercetin resulted in similar concentrations, as observed in monogastric animals [96]. In monogastric species, quercetin bioavailability from rutin is inferior to that of quercetin aglycone [127].

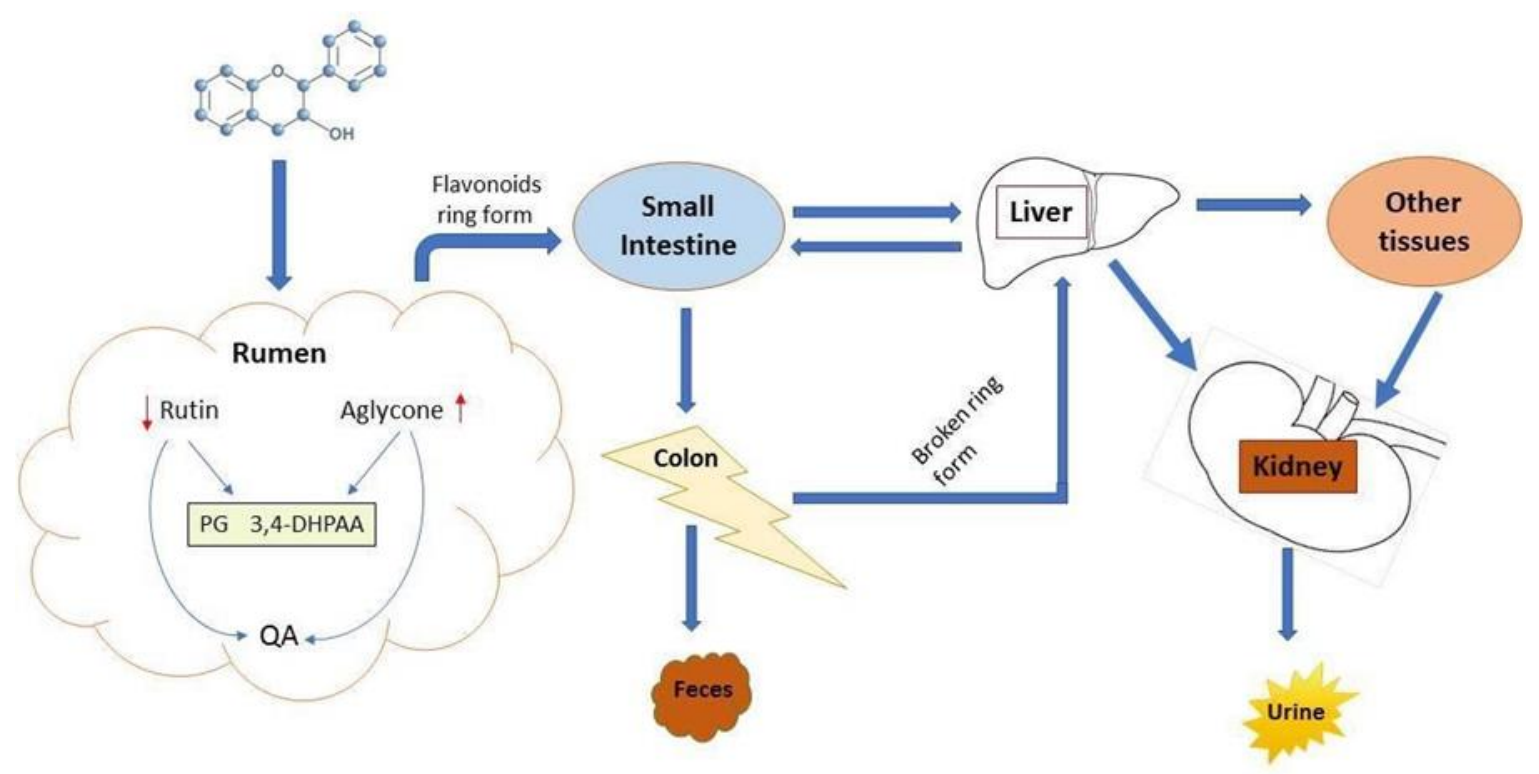

Figure 3. Putative mechanism of flavonoid metabolism and excretion in ruminants.

Bioavailability of a compound depends on its fate within the gut. Ruminal microbes can degrade quercetin and its derivatives in vitro, suggesting that quercetin undergoes intensive microbial fermentation in the rumen [129-132]. Rumen metabolism of quercetin is further demonstrated by the appearance of its degradation products, such as 3,4-dihydroxyphenylacetic acid (3,4-DHPAA); phloroglucinol; and some minor metabolites identified in humans, cows, and pigs $[131,133,134]$. Oral supplementation of quercetin aglycone and rutin in calves resulted in systemic availability of quercetin and its derivatives tamarixetin, isorhamnetin, and kaempferol in neonatal calves [135]. Additionally, because of underdeveloped rumen in neonatal calves, quercetin aglycone had better bioavailability as compared to rutin [136]. However, in adult ruminants, bioavailability of quercetin aglycone decreases, while rutin increases due to microbial fermentation that results in subsequent partial degradation of quercetin $[125,137,138]$.

Because most of the flavonoids in mulberry are in the conjugated form (rutin or aglycone glycosides), it could be perceived that optimum levels of the active form of flavonoids (quercetin) can be achieved in systemic circulation to impart their subsequent antioxidant and metabolic effects as observed in monogastric species. However, further investigations are warranted to elucidate the extent of degradation of flavonoids in the rumen and their subsequent absorption in the lower gut and systemic bioavailability in different ruminants' species. 


\section{Feeding of Mulberry Leaves and Its Flavonoids in Ruminants}

Mulberry leaves are considered a potential feed for both monogastric and ruminant animals. Some studies have revealed that the inclusion of ML in the ruminant diet can efficiently replace other more expensive protein ingredients $[139,140]$. Research has been conducted to demonstrate beneficial effects of ML inclusion in neonatal and growing calves, beef cattle, and lactating dairy cattle.

\subsection{Effects of Mulberry Leaf and Its Flavonoids on Ruminal Development and Calf Health}

Nutritional strategies implemented in the pre-weaning period affect the development of the rumen. The intimate cross-talk between the ruminal microbiome, its metabolites, diet, and the host is responsible for successive changes that occur during development of this important organ. For example, volatile fatty acids (VFA) produced by microbes ultimately determine the size and shape of ruminal papilla. These ruminal papillary structures affect microbial colonization, as it provides a niche environment for certain microbes [141]. Thus, for optimization of gut development and sustained microbial colonization, the time of intestinal colonization after birth or during weaning is the most crucial practical consideration in the life of the young animals. Feeding of MLP improved ruminal papillae morphology including width of stratum granulosum and stratum basale. The latter is the primary site for energy metabolism via ketogenesis [71]. Thus, it is likely that the positive effect of feeding MLFs on nutrient digestibility, dietary metabolizable energy, and ruminal fermentation in preand post-weaning calves arises from potential direct effects on the epithelium [142-144].

Recent studies have shown that feeding MLFs alone and in combination with yeast (Candida tropicalis) decreased fecal score during the pre-weaning period of calves [145]. However, during the post-weaning and overall period, fecal scores were similar among all dietary treatments. This reduction in fecal scores happened simultaneously with the increase in concentrations of IgG, IgM, and IgA in response to MLFs and Candida tropicalis supplementation. During the pre-weaning period, calves fed flavonoids had greater concentrations of serum epidermal growth factor than those fed yeast. Such findings may be attributed to the fact that the molecular structure of flavonoids is quite similar to steroidal hormones (like estradiol); thus, it can potentially regulate the expression of epidermal growth factor and its receptors [145].

One study has also reported no effect of MLFs on ruminal papillae length, width, and tunica muscularis during the pre-weaning period [18]. Lack of response might have been due to bypassing of flavonoids from the underdeveloped rumen. This idea agrees with the observation that major effects of flavonoids have been observed in abomasum and small intestine. For instance, the thickness of tunica mucosa of abomasum and duodenum was decreased with flavonoid supplementation. As the mucosa plays a major role as a barrier against toxins and bacteria, flavonoid aglycones might bind to mucin via non-covalent interactions and help protect the mucus layer [146]. Thus, the lower mucosal thickness induced by flavonoids could help enhance absorption of nutrients rather toxin. Among systemic effects of MLFs, there are reports of positive impacts on serum growth hormone and insulin-like growth factor-1 (IGF-I) in calves at 56 days of age [144]. Additionally, it has been reported that supplementation of MLFs to E. coli challenged calves improved calf health by decreasing fecal scores [147]. Recently, Wang et al. [148] also confirmed that ML promotes goat health by reducing serum leptin concentrations.

\subsection{Effects of Mulberry Leaf and Its Flavonoids on Animal Health and Performance}

Dietary flavonoids not only act as potent antioxidants but also regulate various signaling pathways to guard against oxidative stress at the cellular level [149]. They also possess the ability to enhance absorption and utilization of dietary nutrients, immune response, and lactation performance in animals $[150,151]$. We demonstrated that supplementation of MLFs increased the concentrations of serum metabolic hormones including estradiol, growth hormone, and prolactin in the lactating buffaloes [152]. Responses might have been attributed to the fact that the molecular structure of flavonoids resembles anabolic steroid hormones (phytoestrogens), which might enhance the regulation 
of secretion potentially at the level of hypothalamus-pituitary-axis [153]. Albeit with lower affinity, owing, to structural similarities of flavonoids with natural estrogen along with other steroid hormones and their antagonists [154]. They can mediate changes in gene expression similar to estrogens [155]. Mulberry flavonoids particularly quercetin possess many desirable bioactivities and considerable health-promoting effects in animals. Studies in periparturient dairy cows have shown excellent potential of quercetin to alleviate oxidative stress while reducing the extent of liver damage [156]. This effect of quercetin underscores its potential to sustain performance and promote health during metabolically stressful periods such as early lactation [157].

Several studies have been conducted regarding the effects of supplementation of MLs on growth and production performance of animals (Table 4). Supplementing ML pellets up to $600 \mathrm{~g} / \mathrm{d}$ in a rice straw-based diet significantly increased DM intake in beef cattle [158]. Ensiled MLs and sun-dried mulberry fruit pomace have been used in finishing steer diets without impairing productive performance [21]. Dietary supplementation with MLFs at $2 \mathrm{~g}$ per head had no adverse effect on feed intake in sheep [7]. Similarly, another study demonstrated that provision of mulberry foliage up to $32 \%$ on DM basis in sheep diets resulted in similar DM, organic matter (OM), and NDF intakes [140]. Different tree leaves (zadirachta indica, Melia azedarach, and Leucaena leucocephala) as a forage source for goat has been evaluated by Bakshi and Wadhwa [159] and reported higher DM intake of MLs as compared to others. Liu et al. [16] reported that growing lambs supplemented with different levels of MLs substituting rapeseed meal in ammoniated rice straw diets enhanced feed intake and growth performance. Those results led to the suggestion that MLs could successfully replace rapeseed meal. In the study by Anbarasu et al. [160], a comparison of a leaf meal mixture (Leucaena leucocephala, Morus alba, and Tectona grandis) supplement with groundnut cake or soybean meal was made. Compared with soybean meal, the leaf meal mixture increased daily feed intake and was comparable with the groundnut cake group. However, goats in the leaf meal group had the same average daily weight gain (ADG) as observed with groundnut cake and soybean meal fed goats [160]. The replacement of cottonseed with fresh MLs is possible in growing cattle as the feeding of fresh MLs up to $15 \%$ of dietary DM had no adverse effect on DM intake and ADG but improved the feed conversion ratio from 8 to $14 \%$ as compared with the control diet [51].

Table 4. Effect of mulberry leaf biomass and its flavonoids on ruminant performance.

\begin{tabular}{|c|c|c|c|}
\hline Animal & Dose Rate & Major Findings & References \\
\hline Fattening Hu sheep & $\begin{array}{l}\text { Inclusion of MLP at } 15,30,45, \text { or } 60 \% \\
\text { in concentrate diet }\end{array}$ & $\begin{array}{c}\text { DM intake and average daily gain was } \\
\text { optimized up to } 30 \% \text { MLP }\end{array}$ & [37] \\
\hline Calves & $\begin{array}{c}\text { MLFs at } 2 \text { and } 4 \mathrm{~g} / \mathrm{d} \text { during pre and } \\
\text { poet-weaning respectively }\end{array}$ & $\begin{array}{l}\text { Improved growth performance } \\
\text { and feed digestibility }\end{array}$ & [144] \\
\hline Ewes & $2 \mathrm{~g}$ of MLFs in forage diet (6 weeks) & Reduction in $\mathrm{CH}_{4}$ emission by $12 \%$ & [161] \\
\hline Simmental crossbred steers & Ensiled MLs (16 weeks) & $\begin{array}{l}\text { Higher abundance of Ruminococcus } \\
\text { albus and Ruminococcus albus in } \\
\text { the fecal sample }\end{array}$ & [162] \\
\hline Simmental crossbred steers & $\begin{array}{l}\text { Corn grain and cottonseed meal diet } \\
\text { replaced by } 8 \% \text { ensiled MLs group, } \\
\text { and } 6.3 \% \text { sun-dried mulberry fruit } \\
\text { pomace ( } 16 \text { weeks) }\end{array}$ & $\begin{array}{l}\text { The concentration of total VFA } \\
\text { improved with ensiled MLs compared } \\
\text { to sun-dried mulberry fruit pomace }\end{array}$ & [21] \\
\hline Simmental crossbred steers & $\begin{array}{c}\text { Corn grain and cottonseed meal diet } \\
\text { replaced by } 8 \% \text { ensiled MLs group, } \\
\text { and } 6.3 \% \text { sun-dried mulberry fruit } \\
\text { pomace (16 weeks) }\end{array}$ & $\begin{array}{l}\text { Bacterial community composition was } \\
\text { similar among the three groups }\end{array}$ & [163] \\
\hline Beef cattle & $\begin{array}{c}\text { Mulberry leaf pellet supplementation } \\
\text { at 200, 400, and } 600 \mathrm{~g} / \mathrm{d} \text { with rice } \\
\text { straw }(21 \mathrm{~d})\end{array}$ & $\begin{array}{l}\text { Improved DM intake, ruminal } \mathrm{NH}_{3}-\mathrm{N} \text {, } \\
\text { and cellulolytic bacteria }\end{array}$ & [158] \\
\hline Beef cattle & $\begin{array}{c}\text { Mulberry leaf pellet supplementation } \\
\text { at 200, 400, and } 600 \mathrm{~g} / \mathrm{d} \text { with rice } \\
\text { straw }(21 \mathrm{~d})\end{array}$ & $\begin{array}{c}\text { Improved apparent metabolizable } \\
\text { energy of DM, CP, organic matter, } \\
\text { NDF and ADF }\end{array}$ & [164] \\
\hline Sheep & $\begin{array}{l}\text { Basel diet supplemented with } \\
22 \mathrm{~g} \text { of MLFs }\end{array}$ & $\begin{array}{l}\text { Reduced energy losses of } \\
\qquad \mathrm{CH}_{4} \text { emission }\end{array}$ & [7] \\
\hline
\end{tabular}


Table 4. Cont.

\begin{tabular}{|c|c|c|c|}
\hline Animal & Dose Rate & Major Findings & References \\
\hline Sheep & Mulberry foliage $1.2 \%$ of body weight & $\begin{array}{l}\text { Improved total VFA concentration and } \\
\text { digestibility of ADF and NDF }\end{array}$ & [140] \\
\hline Growing lambs & $\begin{array}{l}\text { Replacement of rapeseed meal with } \\
\text { MLs in ammoniated rice straw diet } \\
\text { (75 days) }\end{array}$ & Improved feed intake and growth rate & [16] \\
\hline Goats & $\begin{array}{c}50 \% \text { replacement of conventional } \\
\text { supplements with a mixture of leaf } \\
\text { meal of (Leucaena leucocephala, M. alba, } \\
\text { and Tectona grandis) }\end{array}$ & $\begin{array}{c}\text { Improved DM intake and comparable } \\
\text { nitrogen balance with } \\
\text { soybean meal group }\end{array}$ & [160] \\
\hline Calves & $\begin{array}{l}\text { MLFs at } 3 \mathrm{~g} / \mathrm{d} \text { during pre- and } \\
\text { post-weaning period (21-80 d of age) }\end{array}$ & $\begin{array}{l}\text { The ADG was improved post-weaning } \\
\text { and overall period with } \\
\text { similar feed Intake }\end{array}$ & {$[145]$} \\
\hline $\begin{array}{l}\text { Calves challenged } \\
\text { with E. coli }\end{array}$ & MLFs at $3 \mathrm{~g} / \mathrm{d}$ & $\begin{array}{l}\text { Improved ADG and feed efficiency } \\
\text { and reduce oxidative stress }\end{array}$ & [18] \\
\hline Buffalo & MLFs at 15,30 , and $45 \mathrm{~g} / \mathrm{d}$ & $\begin{array}{l}\text { Dose-dependent increase in milk yield; } \\
\text { while a higher level of MLFs also } \\
\text { increased milk fat (\%) and protein (\%) }\end{array}$ & {$[152]$} \\
\hline
\end{tabular}

MLs = mulberry leaves, MLFs = mulberry leaf flavonoids, MLP = mulberry leaf powder, ADG = average daily gain, $\mathrm{DM}=$ dry matter, $\mathrm{OM}=$ organic matter, $\mathrm{ME}=$ metabolizable energy, $\mathrm{NE}=$ net energy, $\mathrm{ADF}=$ acid detergent fiber, $\mathrm{NDF}=$ neutral detergent fiber, VFA = volatile fatty acid, $\mathrm{CH}_{4}=$ methane.

Dietary supplementation with MLFs alone or in combination with Candida tropicalis led to greater ADG compared with Candida tropicalis alone [145]. Furthermore, combination of $C$. tropicalis and flavonoids exhibited no synergistic effect on calf health compared to flavonoids alone. However, feed intake was similar among all dietary treatments. In another study, dietary supplementation with MLFs improved ADG and feed efficiency of E. coli challenged calves without exhibiting any adverse effects on feed intake [18]. Additionally, MLFs in neonatal calves improved feed intake, growth rate, and feed digestibility, especially fat digestibility [117]. Similarly, supplementation of MLFs to E. coli-challenged calves improved ADG and feed efficiency [147]. Recently, Ouyang et al. [37] evaluated the feeding to fattening lambs of MLP in high concentrate diets up to $60 \%$ in and reported that $15 \%$ and $30 \%$ level of MLP adequately maintained feed intake and growth performance. However, higher level of MLP (45-60\%) had an adverse effect on feed intake and growth performance.

\subsection{Effects of Mulberry Leaf and Its Flavonoids on Rumen Microbiota and Methanogenesis}

There has been an increased public focus on the contribution of enteric $\mathrm{CH}_{4}$ emissions from ruminants to global climate change. Enteric $\mathrm{CH}_{4}$ is produced by ruminal methanogens through hydrogenotrophic and/or methylotrophic pathways. Nutritional strategies aimed to modulate populations of methanogens and protozoa have proven effective in reducing enteric $\mathrm{CH}_{4}$ emissions in ruminants. Flavonoids possess antimicrobial activities [105] and affect ruminal microbial populations, as propolis flavonoids have shown to shift the populations of protozoa and gram-positive bacteria in the rumen [165]. Santas et al. [166] reported that quercetin and kaempferol can inhibit Gram positive bacteria such as Bacillus cereus, Staphylococcus aureus, Microcroccus luteus, and Listeria monocytogenes. An in vitro study examined the potential of eight flavonoids (epicatechin, luteolin-7-glucoside, quercetin, 
isoquercetin, catechin, gallocatechin, epigallocatechin, and epigallocatechin gallate) to mitigate the $\mathrm{CH}_{4}$ emission and reported that uteolin-7-glucoside ( $50 \mathrm{mg} / \mathrm{g}$ DM) has promising potential to mitigate $\mathrm{CH}_{4}$ and ammonia formation during ruminal fermentation [167]. Another in-vitro study reported that MLFs possess antimicrobial action against Staphylococcus aureus, Bacillus subtilis, and Bacillus pumilus [168]. This is mainly attributed to the ability of flavonoids to interfere with cellular integrity and activity of some Gram negative and Gram positive bacteria as well as protozoa $[165,169]$. A recent study showed that supplementation of paper mulberry in dairy cows can decrease the relative abundance of genera Ruminococcaceae UCG-013 and pathogenic bacteria, Tyzzerella-4 [10]. Owing to their potent antioxidant and antimicrobial activities, MLFs possess an inherent potential to modulate the ruminal microbiome to eventually alter fermentation kinetics and $\mathrm{CH}_{4}$ production.

Studies have reported that MLFs can effectively reduce daily $\mathrm{CH}_{4}$ output in ewes by reducing the population of protozoa and methanogens, while increasing the abundance of $F$. succinogenes, $R$. albus, and B. fibrisolvens [161]. This increase in the population of cellulolytic bacteria was associated with a reduction in protozoal counts. Recently, Olagaray and Bradford [124] reviewed the potential of flavonoids from different plants to reduce $\mathrm{CH}_{4}$ emission in ruminants. Inclusion of different flavonoids (flavone, myricetin, naringin, rutin, quercetin, or kaempferol) reduce in-vitro $\mathrm{CH}_{4}$ production by 5 to $9 \mathrm{~mL} / \mathrm{g}$ DM [170]. Dietary supplementation with MLFs ( $150 \mathrm{mg} / \mathrm{kg}$ of diet) improved in vitro DM digestibility, increased total gas production, and VFA, while decreasing $\mathrm{CH}_{4}$ production in ruminal fluid of sheep [171].

Mulberry leaves and mulberry fruit also promote abundance of total ruminal bacteria in cattle; however, at the genus level, no effect was observed on Prevotella Ruminococcus, Butyrivibrio, and Succiniclasticum [163]. Likewise, an increased abundance of total ruminal bacteria, including amylolytic, proteolytic, and cellulolytic bacteria were reported with supplementation of ML pellets in beef cattle diet. Among cellulolytic bacteria, more pronounced and promising effects were observed on R. albus, which substantially increased with ML supplementation [158]. In addition to direct effects of flavonoids on rumen microbes, their degradation products in the rumen can also effectively modify the microbial metabolism. The breakdown of aglycone ring of flavonoids results in release of phenolic acids, e.g., 3,4-dihydroxyphenylacetic acid from isoquercitrin and quercetin [172,173]. These phenolic end products might take part in the biosynthesis of aromatic amino acids through cinnamic acid pathway. Furthermore, these phenolic compounds such as phenylpropanoic acid and phenylacetic acid have shown to stimulate the growth of cellulolytic bacteria (such as Ruminococcus albus) subsequently leading to enhance the cellulose degradation [174,175].

Studies have also suggested that MLFs could also reduce the risk of ruminal acidosis through increasing the populations of lactate-consuming bacteria (Megasphaera elsdenii) in the rumen of young animals [124]. Dietary supplementation with MLFs increased the relative abundance of different bacterial phyla, including Bacteroidetes, Proteobacteria, TM7, and Verrucomicrobi in E. coli K99 challenged pre-weaned calves [147]. At the genus level, greater abundance of Prevotella, Enterococcus, and Lactobacillus was observed in supplemented calves. Owing to the potent antimicrobial activity of MLFs, a significantly lower copy number of E. coli K99 was observed in treated calves as compared to controls. The lower copy number of E. coli K99 in the mulberry group might be attributed to the increased abundance of lactate producing bacteria in the calf gut [147].

Studies have shown that dietary supplementation with MLFs in Holstein calves increased propionate and total VFA concentration [145]. These desirable changes in rumen fermentation may be attributed to the favorable effect of MLFs on dominant cellulolytic bacteria (such as Ruminococcus albus) as inclusion of ensiled MLs in the diet of finishing steers led to greater abundance of R. albus [162]. Such changes in gut bacteria can potentially increase cellulose degradation leading to better feed utilization and greater VFA yield. Furthermore, a diet containing ensiled MLs and mulberry fruit pomace increased the relative abundance of amylolytic bacteria (particularly S. bovis and Ruminobacter amylophilus), which influenced starch degradation in the upper gut, while consequently increasing luminal glucose content available for absorption [162]. Both MLs and fruit pomace can produce more 
fermentable glucose in the gut and also positively influence protein utilization by microorganisms, subsequently leading to better energetic efficiency in ruminants [20,162]. These findings collectively suggest that MLFs can potentially modulate the ruminal microbiome to mediate fermentation kinetics, subsequently leading to better nutrient utilization and performance in ruminants, while reducing the $\mathrm{CH}_{4}$ emission.

\subsection{Effects of Mulberry Leaf and Its Flavonoids on Feed Digestibility and Ruminal Fermentation Parameters}

Dietary supplementation with MLP linearly increased the digestibility of organic matter and NDF [71]. Similarly, a linear decrease in $\mathrm{NH}_{3}$ and an increase in microbial protein concentrations were observed in sheep (Table 4). Supplementation of MLFs improved apparent digestibility of nitrogen $\left(\mathrm{N}_{2}\right)$ and NDF in ewes, while increasing total VFA. It has been suggested that flavonoids can be used as an alternative source of carbon for the metabolism of the ruminal microbiome, as they are readily degraded in the rumen to yield nonaromatic fermentation products [161]. However, MLFs do not seem to change the ruminal $\mathrm{pH}$ and $\mathrm{NH}_{3}$ concentration in sheep. In fact, increasing levels of ML pellets in rice straw-based diets increased ruminal $\mathrm{NH}_{3}-\mathrm{N}$ concentrations without affecting $\mathrm{pH}[158,164]$. Similarly, increasing the level of ML pellets in beef cattle increased apparent digestibility of DM, CP, $\mathrm{OM}, \mathrm{NDF}$, and ADF. Additionally, MLP also increased the concentration of total VFA, acetate, butyrate, and $\mathrm{A} / \mathrm{P}$ ratio, except for propionate. Furthermore, greater $\mathrm{N}_{2}$ balance was also observed in response to ML pellets in beef cattle [164].

The fact that feeding ML led to similar total DM digestibility in sheep suggested it could be a high-quality forage relative to alfalfa and oat hay [176]. The concentrations of total VFA, acetate, butyrate, and propionate were greater in ML and alfalfa groups as compared with the oat hay group. However, supplementation of MLFs did not change the digestibility of DM, OM, ADF, and NDF compared with control. Furthermore, no effect of MLFs was observed on $\mathrm{N}_{2}$ balance and fecal $\mathrm{N}_{2}$ excretion [7]. The provision of mulberry foliage at $1.2 \%$ of body weight in sheep had no effect on ruminal $\mathrm{pH}$ and $\mathrm{A}: \mathrm{P}$ ratio, but concentration of acetate was greater in the mulberry-fed group. Increased proportion of acetic acid could be due to enhanced digestion of structural carbohydrates, as indicated by greater NDF digestibility [140]. A comparison of different tree leaves indicated that MLs had a relatively high total tract digestibility and $\mathrm{N}_{2}$ retention. Studies have suggested that different tree leaves, including MLs supplemented with mineral mixtures and common salt could serve as excellent complete feeds for small ruminants [159]. Compared with rapeseed meal, greater DM degradation of MLs in the rumen of growing lambs have been reported [16].

The DM, OM, ADF, and NDF digestibility and $\mathrm{N}_{2}$ balance was similar in goats fed with ML meal and soybean meal [160]. Ruminal $\mathrm{pH}$ and $\mathrm{NH}_{3}$-nitrogen were unaffected in response to dietary supplementation with MLFs in calves. However, total VFA and propionate concentrations coupled with abundance of propionate-producing bacteria in the rumen increased with MLFs [125]. Feeding of MLs for 60 days enhanced fiber digestion and utilization, subsequently leading to better lactation performance in goat and dairy cattle [177]. They observed a $36.7 \%$ increase in milk protein and a $4.5-4.9 \%$ increase in lipid content in both species.

\subsection{Effects of Mulberry Leaf Flavonoids on Oxidative Stress and Antioxidant Parameters}

Maintenance of robust antioxidant status is crucial for optimal health and performance particularly in early life. Reactive oxygen species (ROS) are naturally produced during cellular metabolic processes and are neutralized by the antioxidant defense system of the body. Higher production of ROS in stress conditions limit the ability of antioxidant enzymes to maintain balance, leading to oxidative stress [178]. Poor antioxidant response under oxidative stress conditions can adversely affect health and performance of animals $[179,180]$. To avoid severe consequences of oxidative stress, various nutritional strategies including supplementation of antioxidants and pro-antioxidant compounds have been used in farm animals [181]. Superoxide dismutase (SOD) and glutathione peroxidase (GSH-Px) prevents endothelial and mitochondrial dysfunction by inactivating nitric oxide and inhibits hydrogen 
peroxide accumulation in the cell, respectively $[182,183]$; while malondialdehyde (MDA) can affect ion exchange in the cell membrane and can lead to adverse effects, such as changes in ion permeability and enzyme activity [184]. Recently, Hao et al. [10] reported that supplementing paper mulberry increased total antioxidant capacity, SOD, and immune globulin content in dairy cows. Studies have also reported that flavonoids can enhance antioxidant capacity, improve nonspecific immunity, and alleviate oxidative stress by increasing SOD and GSH-Px activity, while decreasing the MDA concentration [185]. The effect is mainly attributed to the ability of flavonoids to act as reducing agents and hydrogen donors to neutralize ROS and remove hydrogen peroxide and superoxide ions [185]. The findings observed in many studies revealed a dual functionality of MLFs to alleviate oxidative stress: (1) by directly interacting with ROS and (2) by increasing the activity of antioxidant enzymes (Table 3).

Different flavonoid compounds possess different antioxidant capacity. For instance, quercetin and morin3-O $\beta$-D-glucopyranoside have better 2,2'-azino-bis 3-ethylbenzothiazoline-6-sulfonic acid and 2,2-diphenyl-1-picrylhydrazyl (DPPH) free radical scavenging activities [186]. Notably, quercetin-3-O- $\beta$-D-glucosyl-(1-6)- $\beta$-glucopyranose and free quercetin have better DPPH free radical scavenging activity. The MLFs possess better antioxidant activity for scavenging of 2,2-azinobis-3-ethylbenz-thiazoline-6-sulphonate (ABTS) radical, DPPH radical, and total reducing power [168]. Furthermore, Kim and Jang [187] confirmed that rutin, isoquercitrin, quercetin-3-O-(6"-O-acetyl)- $\beta$-D-glucopyranose, and quercetin have the highest superoxide radical scavenging ability and stronger anti-AAPH and $\mathrm{Cu}^{2+}$-induced hepatocyte oxidative damage activities. A recent study by Xiaofeng et al. [188] reported comparatively better values of MLs for total antioxidant capacity (60.7 RE mg/g), $\mathrm{Fe}^{2+}$ equivalent (42.9 RE mg/g), reducing power (30.5 RE mg/g), DPPH (21.4 RE mg/g), and ABTS (25.1 RE mg/g). They also reported that antioxidant activities of the five above mentioned tests were positively correlated with the content of isoquercitrin, astragalin, and cumulative flavonoids.

Dietary supplementation with MLFs has shown promising effects regarding the improvement of antioxidant capacity and non-specific immunity as well as the reduction in oxidative stress [18]. Various endogenous antioxidant enzymes (SOD and GSH-Px) can convert oxygen-derived free radicals into less toxic forms [189]. Supplementation of MLFs have shown to effectively reduce the oxidative stress by decreasing blood SOD and GSH-Px activities in calves challenged with E. coli [18]. Recently, Ouyang et al. [37] observed a significant effect of MLP on different antioxidant enzymes in the liver of fattening lambs. The mRNA levels of $\mathrm{Cu} / \mathrm{Zn}$ SOD and GSH-Px were increased in a dose-dependent fashion with the supplementation of MLs (15\%), revealing the potential ability of flavonoids to activate antioxidant defense system [37]. The MLFs can provide defense against oxidative stress by up-regulating the expression of antioxidant genes mediated by an electrophile responsive element [190]. Silage of ML also has the ability to enhance the antioxidant and immune status of dairy cows [10].

Earlier studies in mice reported that quercetin (a major flavonoid present in ML) can effectively up-regulate the expression of the heat shock proteins (HSP), particularly HSP70 through mediating the ERK/PPAR $\gamma$ signaling pathways [191]. Moreover, the extent of such effects induced by flavonoids on HSP was dependent on the molecular weight (family) of HSPs [191]. Recently, dietary supplementation with MLFs revealed a substantial increase in the expression of serum HSP70 and 90 in lactating buffaloes during the summer season [152]. Furthermore, MLFs significantly reduced the level of a biomarker (MDA) for oxidative stress in buffaloes revealing its potent ability to alleviate oxidative stress. A remarkable decrease in MDA levels up to 75\% was observed in buffaloes supplementedwith a higher level of MLFs (45 g/d) buffaloes as compared to the control group [152]. These findings support earlier studies regarding a dose-dependent effect of MLFs to mediate ROS [192]. These findings provide strong evidence about the potent ability of MLFs to alleviate oxidative stress caused by different factors, including adverse climate, weaning, physiological state (metabolic transition, early lactation, etc.), and disease. 


\section{Conclusions}

The studies reviewed in this manuscript reveal that MLs are a potential resource for livestock feeding owing to their high protein and energy contents coupled with better palatability. During the periods of forage shortage, MLs can serve as a useful feeding resource in ruminants. Flavonoids present in MLs also possess significant antioxidant, antimicrobial, and anti-inflammatory potential. Under the recent scenario of climate change and ban on antibiotics, green feed additives are essentially required to address the heat/oxidative stress, microbial infections, and metabolic disorders in livestock. The leaves of mulberry are rich in protein $(14.0-34.2 \%)$, minerals $(2.42-4.71 \% \mathrm{Ca}, 0.23-0.97 \% \mathrm{P})$, and metabolizable energy (1130-2240 kcal/kg) with considerably higher digestibility (75-85\%) that make it comparable to high-quality concentrate ration for dairy cattle. With all its rich nutrients and bioactive phytochemicals, ML and its flavonoids possess sufficient potential to address existing and future challenges of livestock feeding. The flavonoid contents in ML biomass confer unique antioxidant properties and can potentially help alleviate oxidative stress in animals under stressful periods such as the neonatal period, weaning, and periparturient period. Most importantly, feeding of ML biomass and its flavonoids can effectively reduce enteric $\mathrm{CH}_{4}$ emission from livestock, which is a challenging task under recent climate change scenario.

Despite the excellent potential of MLFs observed in mice and monogastric models, studies regarding the supplementation with MLFs in ruminants are limited. Therefore, further investigation is required to elucidate optimum levels of dietary supplementation with MLFs to ensure proper bioavailability and efficacy in ruminants in terms of promoting health and performance. The potential of MLFs to scavenge ROS and alleviate oxidative stress through enhancing the capacity of endogenous antioxidant defense system needs to be explored at the molecular level to elucidate the mechanism of action of different flavonoids. Furthermore, there is a need to investigate potential effects of MLFs on the endocrine system, different signaling pathways, and their subsequent metabolic effects, particularly regarding the regulation of carbohydrate and lipid metabolic pathways in ruminants.

Author Contributions: Conceptualization, F.H. and M.L.; software, M.A.A.; validation, J.H. and M.L.; resources, M.A.A.; data curation, M.S.R.; writing—original draft preparation, M.A.A. and F.H.; writing-review and editing, J.J.L., F.H.; visualization, M.L.; supervision, J.H.; project administration, J.H.; funding acquisition, J.H. All authors have read and agreed to the published version of the manuscript.

Funding: This research was funded by the Guangxi Key Research \& Development Program, (grant number AB16380040) and the Fundamental Research Funds for the Buffalo Research Institute, CAAS (grant number 200508), and the APC will be covered by the same grants.

Acknowledgments: We acknowledge the kind inputs of Isaac J. Salferc, Dairy and Food Science Department, South Dakota State University, USA for editing and Abdelfattah Z.M. Salem, Facultadde Medicina Veterinariay Zootecnia, Universidad Autónoma del Estado de México, Estado de México, México during revision of the manuscript.

Conflicts of Interest: The authors declare no conflict of interest.

\section{References}

1. Ash, A. The effect of supplementation with leaves from the leguminous trees Sesbania grandiflora, Albizia chinensis and Gliricidia sepium on the intake and digestibility of guinea grass hay by goats. Anim. Feed Sci. Technol. 1990, 28, 225-232. [CrossRef]

2. Emile, J.-C. Nutritive value and degradability of leaves from temperate woody resources for feeding ruminants in summer. In Proceedings of the 3rd European Agroforestry Conference Montpellier, Montpellier, France, 23-25 May 2016.

3. Ku-Vera, J.C.; Castelán-Ortega, O.; Galindo-Maldonado, F.; Arango, J.; Chirinda, N.; Jiménez-Ocampo, R.; Valencia-Salazar, S.; Flores-Santiago, E.; Montoya-Flores, M.D.; Molina-Botero, I.C. Strategies for enteric methane mitigation in cattle fed tropical forages. Animal 2020, 14, s453-s463. [CrossRef] [PubMed]

4. Habib, G.; Khan, N.; Sultan, A.; Ali, M. Nutritive value of common tree leaves for livestock in the semi-arid and arid rangelands of Northern Pakistan. Livest. Sci. 2016, 184, 64-70. [CrossRef] 
5. Omar, S.; Shayo, C.; Uden, P. Voluntary intake and digestibility of mulberry (Morus alba) diets by growing goats. Trop. Grassl. 1999, 33, 177-181.

6. Yao, J.; Yan, B.; Wang, X.; Liu, J. Nutritional evaluation of mulberry leaves as feeds for ruminants. Livest. Res. Rural Dev. 2000, 12, 9-16.

7. Chen, D.; Chen, X.; Tu, Y.; Wang, B.; Lou, C.; Ma, T.; Diao, Q. Effects of mulberry leaf flavonoid and resveratrol on methane emission and nutrient digestion in sheep. Anim. Nutr. 2015, 1, 362-367. [CrossRef]

8. Huo, Y. Mulberry cultivation and utilization in China. FAO Anim. Prod. Health Pap. 2000, 1, 11-44.

9. Sánchez, M.D. World distribution and utilization of mulberry and its potential for animal. In Proceedings of the Mulberry for Animal Production: Proceedings of an Electronic Conference Carried out between May and August 2000; Food and Agriculture Organization: Rome, Italy, 2002; p. 1.

10. Hao, Y.; Huang, S.; Si, J.; Zhang, J.; Gaowa, N.; Sun, X.; Lv, J.; Liu, G.; He, Y.; Wang, W. Effects of Paper Mulberry Silage on the Milk Production, Apparent Digestibility, Antioxidant Capacity, and Fecal Bacteria Composition in Holstein Dairy Cows. Animal 2020, 10, 1152. [CrossRef] [PubMed]

11. Ba, N.X.; Giang, V.D.; Ngoan, L.D. Ensiling of mulberry foliage (Morus alba) and the nutritive value of mulberry foliage silage for goats in central Vietnam. Livest. Res. Rural Dev. 2005, 17, 23-25.

12. Simbaya, J.; Chibinga, O.; Salem, A.Z. Nutritional evaluation of selected fodder trees: Mulberry (Molus alba Lam.), Leucaena (Leucaena luecocephala Lam de Wit.) and Moringa (Moringa oleifera Lam.) as dry season protein supplements for grazing animals. Agrofor. Syst. 2020, 94, 1189-1197. [CrossRef]

13. Marchii, H. Varietal differences of nitrogen and amino acid contents in mulberry leaves. Acta Sericologica Entomol. 1989, 1, 51-61.

14. Tesfay, G.; Tamir, B.; Berhane, G. Substitution of mulberry leaf meal on feed intake, body weight and carcass characteristics of Tigray highland lambs. Indones. J. Anim. Vet. Sci. 2018, 23, 28-37. [CrossRef]

15. Phiny, C.; Preston, T.; Ly, J. Mulberry (Morus alba) leaves as protein source for young pigs fed rice-based diets: Digestibility studies. Livest. Res. Rural Dev. 2003, 15, 1.

16. Liu, J.; Yao, J.; Yan, B.; Yu, J.; Shi, Z. Effects of mulberry leaves to replace rapeseed meal on performance of sheep feeding on ammoniated rice straw diet. Small Rumin. Res. 2001, 39, 131-136. [CrossRef]

17. Cheong, S.; Kim, K.; Jeon, B.; Park, P.; Hwang, I.; Choi, N.; Kim, E.; Hong, S.; Park, J.; Sung, S. Effect of mulberry silage supplementation during late fattening stage of Hanwoo (Bos taurus coreanae) steer on antioxidative enzyme activity within the longissimus muscle. Anim. Prod. Sci. 2012, 52, 240-247. [CrossRef]

18. Wang, B.; Yang, C.; Diao, Q.; Tu, Y. The influence of mulberry leaf flavonoids and Candida tropicalis on antioxidant function and gastrointestinal development of preweaning calves challenged with Escherichia coli O141: K99. J. Dairy Sci. 2018, 101, 6098-6108. [CrossRef]

19. Liu, Y.; Li, Y.; Peng, Y.; He, J.; Xiao, D.; Chen, C.; Li, F.; Huang, R.; Yin, Y. Dietary mulberry leaf powder affects growth performance, carcass traits and meat quality in finishing pigs. J. Anim. Physiol. Anim. Nutr. 2019, 103, 1934-1945. [CrossRef]

20. Zhou, B.; Meng, Q.; Ren, L.; Shi, F.; Wei, Z.; Zhou, Z. Evaluation of chemical composition, in situ degradability and in vitro gas production of ensiled and sun-dried mulberry pomace. J. Anim. Feed Sci. 2012, 21, 188-197. [CrossRef]

21. Zhou, Z.; Zhou, B.; Ren, L.; Meng, Q. Effect of ensiled mulberry leaves and sun-dried mulberry fruit pomace on finishing steer growth performance, blood biochemical parameters, and carcass characteristics. PLOS ONE 2014, 9, e85406. [CrossRef]

22. Benavides, J. Utilisation of mulberry in animal production systems (part 1/3). In FAO Electronic Conference on Mulberry for Animal Production; FAO: Rome, Italy, 2000.

23. Salem, A.Z.; Kunst, C.R.; Jose, S. Alternative animal feeds from agroforestry plants. Agrofor. Syst. 2020, 94, 1133-1138. [CrossRef]

24. Ebrahim, H.; Negussie, F. Effect of secondary compounds on nutrients utilization and productivity of ruminant animals: A review. J. Agric. Sci. Prac. 2020, 5, 60-73.

25. Naboulsi, I.; Aboulmouhajir, A.; Kouisni, L.; Bekkaoui, F.; Yasri, A. Plants extracts and secondary metabolites, their extraction methods and use in agriculture for controlling crop stresses and improving productivity: A review. Acad. J. Med. Plants 2018, 6, 223-240.

26. Balcells, J.; Aris, A.; Serrano, A.; Seradj, A.; Crespo, J.; Devant, M. Effects of an extract of plant flavonoids (Bioflavex) on rumen fermentation and performance in heifers fed high-concentrate diets. J. Anim. Sci. 2012, 90, 4975-4984. [CrossRef] 
27. Polumackanycz, M.; Sledzinski, T.; Goyke, E.; Wesolowski, M.; Viapiana, A. A comparative study on the phenolic composition and biological activities of Morus alba L. commercial samples. Molecules 2019, $24,3082$. [CrossRef]

28. Cirne, L.; Sobrinho, A.; Oliveira, E.; Carvalho, G.; Moreno, G.; Valença, R.; Almeida, F.; Endo, V.; Zeola, N. Nutritional characteristics of meat from lambs fed diets containing mulberry hay. S. Afr. J. Anim. Sci. 2019, 49, 20-28. [CrossRef]

29. Peng, C.-H.; Lin, H.-T.; Chung, D.-J.; Huang, C.-N.; Wang, C.-J. Mulberry Leaf Extracts prevent obesity-induced NAFLD with regulating adipocytokines, inflammation and oxidative stress. J. Food Drug Anal. 2018, 26, 778-787. [CrossRef]

30. Thaipitakwong, T.; Numhom, S.; Aramwit, P. Mulberry leaves and their potential effects against cardiometabolic risks: A review of chemical compositions, biological properties and clinical efficacy. Pharm. Biol. 2018, 56, 109-118. [CrossRef]

31. Wen, P.; Hu, T.-G.; Linhardt, R.J.; Liao, S.-T.; Wu, H.; Zou, Y.-X. Mulberry: A review of bioactive compounds and advanced processing technology. Trends Food Sci. Technol. 2019, 83, 138-158. [CrossRef]

32. Besle, J.-M.; Viala, D.; Martin, B.; Pradel, P.; Meunier, B.; Berdagué, J.-L.; Fraisse, D.; Lamaison, J.; Coulon, J.B. Ultraviolet-absorbing compounds in milk are related to forage polyphenols. J. Dairy Sci. 2010, 93, 2846-2856. [CrossRef]

33. Stoldt, A.-K.; Derno, M.; Das, G.; Weitzel, J.M.; Wolffram, S.; Metges, C.C. Effects of rutin and buckwheat seeds on energy metabolism and methane production in dairy cows. J. Dairy Sci. 2016, 99, 2161-2168. [CrossRef]

34. Seradj, A.R.; Abecia, L.; Crespo, J.; Villalba, D.; Fondevila, M.; Balcells, J. The effect of Bioflavex ${ }^{\circledR}$ and its pure flavonoid components on in vitro fermentation parameters and methane production in rumen fluid from steers given high concentrate diets. Anim. Feed Sci. Technol. 2014, 197, 85-91. [CrossRef]

35. Zhao, X.; Yang, R.; Bi, Y.; Bilal, M.; Kuang, Z.; Iqbal, H.; Luo, Q. Effects of Dietary Supplementation with Mulberry (Morus alba L.) Leaf Polysaccharides on Immune Parameters of Weanling Pigs. Animal 2020, 10, 35. [CrossRef]

36. Mohamaden, W.I.; Hegab, I.M.; Shang-li, S. In situ ruminal degradation kinetics and blood metabolites as affected by feeding different sources of tannin and flavonoids to small-tailed Han rams. Livest. Sci. 2020, 239, 104029. [CrossRef]

37. Ouyang, J.; Hou, Q.; Wang, M.; Zhao, W.; Feng, D.; Pi, Y.; Sun, X.-z. Effects of dietary mulberry leaf powder on growth performance, blood metabolites, meat quality and antioxidant enzyme related gene expression of fattening Hu lambs. Can. J. Anim. Sci. 2020, 100, 510-521. [CrossRef]

38. Dong, T.; Liu, Z.; Xuan, Q.; Wang, Z.; Ma, W.; Zhang, Q. Tumor LDH-A expression and serum LDH status are two metabolic predictors for triple negative breast cancer brain metastasis. Sci. Rep. 2017, 7, 1-8. [CrossRef]

39. Radi, Z.A.; Koza-Taylor, P.H.; Bell, R.R.; Obert, L.A.; Runnels, H.A.; Beebe, J.S.; Lawton, M.P.; Sadis, S. Increased serum enzyme levels associated with kupffer cell reduction with no signs of hepatic or skeletal muscle injury. Am. J. Pathol. 2011, 179, 240-247. [CrossRef]

40. Nguyen-Lefebvre, A.T.; Horuzsko, A. Kupffer cell metabolism and function. J. Enzymol. Metab. $2015,1,101$.

41. Khan, M.A.; Rahman, A.A.; Islam, S.; Khandokhar, P.; Parvin, S.; Islam, M.B.; Hossain, M.; Rashid, M.; Sadik, G.; Nasrin, S. A comparative study on the antioxidant activity of methanolic extracts from different parts of Morus alba L.(Moraceae). BMC Res. Notes 2013, 6, 24. [CrossRef]

42. Rohela, G.K.; Muttanna, P.S.; Kumar, R.; Chowdhury, S.R. Mulberry (Morus spp.): An ideal plant for sustainable development. Trees For. People 2020, 2, 2666-7193. [CrossRef]

43. Alfrey, P. Mo' Mulberry-A guide to probably everything you need to know about growing Mulberry. Noteworthy J. Blog 2017. Available online: https://blog.usejournal.com/mo-mulberry-the-essential-guide-toall-you-need-to-know-about-mulberry-28a0c11b611 (accessed on 10 October 2020).

44. Sánchez-Salcedo, E.M.; Amorós, A.; Hernández, F.; Martínez, J.J. Physicochemical properties of white (Morus alba) and black (Morus nigra) mulberry leaves, a new food supplement. J. Food Nutr. Res. 2017, 5, 253-261.

45. Yang, X.; Yang, L.; Zheng, H. Hypolipidemic and antioxidant effects of mulberry (Morus alba L.) fruit in hyperlipidaemia rats. Food Chem. Toxicol. 2010, 48, 2374-2379. [CrossRef]

46. Zhang, H.; Ma, Z.F.; Luo, X.; Li, X. Effects of mulberry fruit (Morus alba L.) consumption on health outcomes: A mini-review. Antioxidants 2018, 7, 69. [CrossRef] [PubMed] 
47. Fallon, E.; Zhong, L.; Furne, J.K.; Levitt, M.D. A mixture of extracts of black and green teas and mulberry leaf did not reduce weight gain in rats fed a high-fat diet. Altern. Med. Rev. 2008, 13, 43. [PubMed]

48. Oh, K.-S.; Ryu, S.Y.; Lee, S.; Seo, H.W.; Oh, B.K.; Kim, Y.S.; Lee, B.H. Melanin-concentrating hormone-1 receptor antagonism and anti-obesity effects of ethanolic extract from Morus alba leaves in diet-induced obese mice. J. Ethnopharmacol. 2009, 122, 216-220. [CrossRef] [PubMed]

49. Gupta, S.; Lakshmi, A.J.; Manjunath, M.; Prakash, J. Analysis of nutrient and antinutrient content of underutilized green leafy vegetables. LWT-Food Sci. Technol. 2005, 38, 339-345. [CrossRef]

50. Kandylis, K.; Hadjigeorgiou, I.; Harizanis, P. The nutritive value of mulberry leaves (Morus alba) as a feed supplement for sheep. Trop. Anim. Health Prod. 2009, 41, 17-24. [CrossRef]

51. Vu, C.C.; Verstegen, M.; Hendriks, W.; Pham, K. The nutritive value of mulberry leaves (Morus alba) and partial replacement of cotton seed in rations on the performance of growing Vietnamese cattle. Asian-Australas J. Anim. Sci. 2011, 24, 1233-1242. [CrossRef]

52. Wanapat, M.; Kang, S.; Polyorach, S. Development of feeding systems and strategies of supplementation to enhance rumen fermentation and ruminant production in the tropics. J. Anim. Sci. Biotechnol. 2013, 4, 32. [CrossRef]

53. Chandang, P.; Thongprajukaew, K.; Chotimanothum, B.; Kovitvadhi, A.; Kovitvadhi, U.; Pakkong, P. The effects on in vitro digestibility from different developmental stages of silkworm larvae, Bombyx mori (Lepidoptera: Bombycidae) and position of mulberry leaves, Morus alba (Rosales: Moraceae). J. Asia-Pac. Entomol. 2017, 20, 1134-1139. [CrossRef]

54. Flaczyk, E.; Kobus-Cisowska, J.; Przeor, M.; Korczak, J.; Remiszewski, M.; Korbas, E.; Buchowski, M. Chemical characterization and antioxidative properties of Polish variety of Morus alba L. leaf aqueous extracts from the laboratory and pilot-scale processes. Agric. Sci. 2013, 4, 141. [CrossRef]

55. Srivastava, S.; Kapoor, R.; Thathola, A.; Srivastava, R.P. Nutritional quality of leaves of some genotypes of mulberry (Morus alba). Int. J. Food Sci. Nutr. 2006, 57, 305-313. [CrossRef] [PubMed]

56. Devi, B.; Sharma, N.; Kumar, D.; Jeet, K. Morus alba Linn: A phytopharmacological review. Int. J. Pharm. Pharm. Sci. 2013, 5, 14-18.

57. Jeszka-Skowron, M.; Flaczyk, E.; Jeszka, J.; Krejpcio, Z.; Król, E.; Buchowski, M.S. Mulberry leaf extract intake reduces hyperglycaemia in streptozotocin (STZ)-induced diabetic rats fed high-fat diet. J. Funct. Foods 2014, 8, 9-17. [CrossRef]

58. Yu, Y.; Li, H.; Zhang, B.; Wang, J.; Shi, X.; Huang, J.; Yang, J.; Zhang, Y.; Deng, Z. Nutritional and functional components of mulberry leaves from different varieties: Evaluation of their potential as food materials. Int. J. Food Prop. 2018, 21, 1495-1507. [CrossRef]

59. Radojković, M.; Zeković, Z.; Mašković, P.; Vidović, S.; Mandić, A.; Mišan, A.; Đurović, S. Biological activities and chemical composition of Morus leaves extracts obtained by maceration and supercritical fluid extraction. J. Supercrit. Fluid 2016, 117, 50-58. [CrossRef]

60. Adeduntan, S.; Oyerinde, A. Evaluation of chemical and antinutritional characteristics of obeche (Triplochition scleroxylon) and some mulberry (Morus alba) leaves. Int. J. Biol Chem Sci. 2009, 3, 681-687. [CrossRef]

61. Bamikole, M.; Ikhatua, M.; Ikhatua, U.; Ezenwa, I. Nutritive value of mulberry (Morus spp.) leaves in the growing rabbits in Nigeria. Pak. J. Nutr. 2005, 4, 231-236. [CrossRef]

62. Cai, M.; Mu, L.; Wang, Z.-1.; Liu, J.-y.; Liu, T.-1.; Wanapat, M.; Huang, B.-z. Assessment of mulberry leaf as a potential feed supplement for animal feeding in PR China. Asian-Australas J. Anim. Sci. 2019, 32, 1145. [CrossRef]

63. Guven, I. Effect of species on Nutr.itive value of mulberry leaves. Kafkas Univ. Vet. Fak. Derg. 2012, 18, 865-869.

64. Todaro, M.; Bonanno, A.; Tornambè, G.; Di Grigoli, A.; Luisa Scatassa, M.; Giaccone, P. Utilization of mulberry leaves (Morus latifolia cv. Kokusou 21) in diets for dairy ewes. Ital. J. Anim. Sci. 2009, 8, 438-440. [CrossRef]

65. Wang, W.; Yang, H.; Bo, Y.; Ding, S.; Cao, B. Nutr.ient composition, polyphenolic contents, and in situ protein degradation kinetics of leaves from three mulberry species. Livest. Sci. 2012, 146, 203-206. [CrossRef]

66. Al-Kirshi, R.; Alimon, A.; Zulkifli, I.; Zahari, M.; Sazili, A. The chemical composition and Nutritive value of mulberry leaf as a protein source in poultry diets. In Proceedings of the International Seminar on Animal Industry, Jakarta, Indonesia, 5-6 July 2012. 
67. Doliș, M.; Donose, R.; Simeanu, C.; Usturoi, A.; Rațu, R. Research regarding chemical composition of the mulberry leaves from Kokuso 21 variety. An. Univ. Oradea Fasc. Ecotoxicol. Zooteh. Tehnol. Ind. Aliment. 2016, 15, 207-212.

68. Ganai, A.; Mattoo, F.; Singh, P.; Ahmad, H.; Samoon, M. Chemical composition of some feeds, fodders and plane of Nutr.ition of livestock of Kashmir valley. SKUAST J. Res. 2006, 8, 145-151.

69. Iqbal, S.; Younas, U.; Chan, K.W.; Sarfraz, R.A.; Uddin, M. Proximate composition and antioxidant potential of leaves from three varieties of Mulberry (Morus sp.): A comparative study. Int. J. Mol. Sci. 2012, 13, 6651-6664. [CrossRef]

70. Kang, J.; Wang, R.; Tang, S.; Wang, M.; Tan, Z.; Bernard, L. Chemical composition and in vitro ruminal fermentation of pigeonpea and mulberry leaves. Agrofor. Syst. 2019, 94, 1521-1528. [CrossRef]

71. Ouyang, J.; Wang, M.; Hou, Q.; Feng, D.; Pi, Y.; Zhao, W. Effects of Dietary Mulberry Leaf Powder in Concentrate on the Rumen Fermentation and Ruminal Epithelium in Fattening Hu Sheep. Animal 2019, 9, 218. [CrossRef]

72. Sahoo, A.; Singh, B.; Sharma, O. Evaluation of feeding value of Eupatorium adenophorum in combination with mulberry leaves. Livest. Sci. 2011, 136, 175-183. [CrossRef]

73. Sun, C.; Wu, W.; Ma, Y.; Min, T.; Lai, F.; Wu, H. Physicochemical, functional properties, and antioxidant activities of protein fractions obtained from mulberry (morus atropurpurea roxb.) leaf. Int. J. Food Prop. 2017, 20, S3311-S3325. [CrossRef]

74. Kamalak, A.; Canbolat, O.; Gurbuz, Y.; Ozay, O.; Ozkan, C.; Sakarya, M. Chemical composition and in vitro gas production characteristics of several tannin containing tree leaves. Livest. Res. Rural Dev. 2004, 16, 2004.

75. St-Pierre, N.R. Meta-analyses of experimental data in the animal Sciences. Rev. Bras. Zootec. 2007, 36, 343-358. [CrossRef]

76. Ustundag, A.O.; Ozdogan, M. Usage possibilities of mulberry leaves in poultry Nutrition. Sci. Pap. Ser. D Anim. Sci. Int. Sess. Sci. Commun. Fac. Anim. Sci. 2015, 58, 170-178.

77. Hassan, F.; Arshad, M.A.; Ebeid, H.M.; Rehman, M.S.; Khan, M.S.; Shahid, S.; Yang, C. Phytogenic additives can modulate rumen microbiome to mediate fermentation kinetics and methanogenesis through exploiting diet- microbe interaction. Front. Vet. Sci. 2020, 7, 892. [CrossRef]

78. McSweeney, C.; Palmer, B.; McNeill, D.; Krause, D. Microbial interactions with tannins: Nutritional consequences for ruminants. Anim. Feed Sci. Technol. 2001, 91, 83-93. [CrossRef]

79. Asano, N.; Nash, R.J.; Molyneux, R.J.; Fleet, G.W. Sugar-mimic glycosidase inhibitors: Natural occurrence, biological activity and prospects for therapeutic application. Tetrahedron Asymmetry 2000, 11, 1645-1680. [CrossRef]

80. Hu, X.-Q.; Jiang, L.; Zhang, J.-G.; Deng, W.; Wang, H.-L.; Wei, Z.-J. Quantitative determination of 1-deoxynojirimycin in mulberry leaves from 132 varieties. Ind. Crops Prod. 2013, 49, 782-784. [CrossRef]

81. Kwon, H.J.; Chung, J.Y.; Kim, J.Y.; Kwon, O. Comparison of 1-deoxynojirimycin and aqueous mulberry leaf extract with emphasis on postprandial hypoglycemic effects: In vivo and in vitro studies. J. Agric. Food Chem. 2011, 59, 3014-3019. [CrossRef] [PubMed]

82. Song, W.; Wang, H.-J.; Bucheli, P.; Zhang, P.-F.; Wei, D.-Z.; Lu, Y.-H. Phytochemical profiles of different mulberry (Morus sp.) species from China. J. Agric. Food Chem. 2009, 57, 9133-9140. [CrossRef]

83. Rahman, M.M.; Rahman, M.R.; Niimi, M.; Khadijah, W.E.W.; Akashi, R.; Abdullah, R. Effects of different levels of oxalic acid administration on feed intake and Nutrient digestibility in goats. Sains Malays. 2017, 46, 515-519. [CrossRef]

84. Rahman, M.; Nakagawa, T.; Niimi, M.; Fukuyama, K.; Kawamura, O. Effects of feeding oxalate containing grass on intake and the concentrations of some minerals and parathyroid hormone in blood of sheep. Asian-Australas J. Anim. Sci. 2011, 24, 940-945. [CrossRef]

85. Rahman, M.; Abdullah, R.; Wan Khadijah, W. A review of oxalate poisoning in domestic animals: Tolerance and performance aspects. J. Anim. Physiol. Anim. Nutr. 2013, 97, 605-614. [CrossRef] [PubMed]

86. Soto-Blanco, B.; Stegelmeier, B.; Pfister, J.; Gardner, D.; Panter, K. Comparative effects of prolonged administration of cyanide, thiocyanate and chokecherry (Prunus virginiana) to goats. J. Appl. Toxicol. An. Int. J. 2008, 28, 356-363. [CrossRef]

87. Winkel-Shirley, B. Flavonoid biosynthesis. A colorful model for genetics, biochemistry, cell biology, and biotechnology. Plant. Physiol 2001, 126, 485-493. [CrossRef] [PubMed] 
88. Ju, W.-T.; Kwon, O.-C.; Kim, H.-B.; Sung, G.-B.; Kim, H.-W.; Kim, Y.-S. Qualitative and quantitative analysis of flavonoids from 12 species of Korean mulberry leaves. J. Food Sci. Technol 2018, 55, 1789-1796. [CrossRef]

89. Sugiyama, M.; Katsube, T.; Koyama, A.; Itamura, H. Varietal differences in the flavonol content of mulberry (Morus spp.) leaves and genetic analysis of quercetin 3-(6-malonylglucoside) for component breeding. J. Agric. Food Chem. 2013, 61, 9140-9147. [CrossRef] [PubMed]

90. Guardia, T.; Rotelli, A.E.; Juarez, A.O.; Pelzer, L.E. Anti-inflammatory properties of plant flavonoids. Effects of rutin, quercetin and hesperidin on adjuvant arthritis in rat. Il Farmaco. 2001, 56, 683-687. [CrossRef]

91. Rogerio, A.; Kanashiro, A.; Fontanari, C.; Da Silva, E.; Lucisano-Valim, Y.; Soares, E.; Faccioli, L. Anti-inflammatory activity of quercetin and isoquercitrin in experimental murine allergic asthma. Inflamm. Res. 2007, 56, 402-408. [CrossRef]

92. Narayana, K.R.; Reddy, M.S.; Chaluvadi, M.; Krishna, D. Bioflavonoids classification, pharmacological, biochemical effects and therapeutic potential. Indian J. Pharmacol. 2001, 33, 2-16.

93. Crozier, A.; Jaganath, I.B.; Clifford, M.N. Phenols, polyphenols and tannins: An overview. In Plant Secondary Metabolites: Occurrence, Structure and Role in the Human Diet; Crozier, M.N.C.A., Ashihara, H., Eds.; Blackwell: Oxford, UK, 2006; pp. 1-24.

94. Middleton, E., Jr.; Drzewiecki, G. Flavonoid inhibition of human basophil histamine release stimulated by various agents. Biochem. Pharmacol. 1984, 33, 3333-3338. [CrossRef]

95. Hollman, P.C.; Bijsman, M.N.; Van Gameren, Y.; Cnossen, E.P.; De Vries, J.H.; Katan, M.B. The sugar moiety is a major determinant of the absorption of dietary flavonoid glycosides in man. Free Radic. Res. 1999, 31, 569-573. [CrossRef]

96. Gohlke, A.; Ingelmann, C.; Nürnberg, G.; Starke, A.; Wolffram, S.; Metges, C. Bioavailability of quercetin from its aglycone and its glucorhamnoside rutin in lactating dairy cows after intraduodenal administration. J. Dairy Sci. 2013, 96, 2303-2313. [CrossRef]

97. Matsuoka, T.; Kimura, T.; Muraoka, N. Research of the available constituents from mulberry tree. Tohoku Agric. Res. 1994, 47, 361-362.

98. Onogi, A.; Osawa, K.; Yasuda, H.; Sakai, A.; Morita, H.; Itokawa, H. Flavonol Glycosides from the Leaves of Morus alba L. J. Pharm. Sci. 1993, 47, 423-425.

99. He, X.; Chen, X.; Ou, X.; Ma, L.; Xu, W.; Huang, K. Evaluation of flavonoid and polyphenol constituents in mulberry leaves using HPLC fingerprint analysis. Int. J. Food Sci. Technol. 2020, 55, 526-533. [CrossRef]

100. Zhishen, J.; Mengcheng, T.; Jianming, W. The determination of flavonoid contents in mulberry and their scavenging effects on superoxide radicals. Food Chem. 1999, 64, 555-559. [CrossRef]

101. Erlund, I. Review of the flavonoids quercetin, hesperetin, and naringenin. Dietary sources, bioactivities, bioavailability, and epidemiology. Nutr. Res. 2004, 24, 851-874. [CrossRef]

102. Middleton, E.; Kandaswami, C.; Theoharides, T.C. The effects of plant flavonoids on mammalian cells: Implications for inflammation, heart disease, and cancer. Pharmacol. Rev. 2000, 52, 673-751.

103. Katsube, T.; Yamasaki, M.; Shiwaku, K.; Ishijima, T.; Matsumoto, I.; Abe, K.; Yamasaki, Y. Effect of flavonol glycoside in mulberry (Morus alba L.) leaf on glucose metabolism and oxidative stress in liver in diet-induced obese mice. J. Sci. Food Agric. 2010, 90, 2386-2392. [CrossRef]

104. Ren, M.Q.; Kuhn, G.; Wegner, J.; Chen, J. Isoflavones, substances with multi-biological and clinical properties. Eur. J. Nutr. 2001, 40, 135-146. [CrossRef]

105. Cushnie, T.T.; Lamb, A.J. Antimicrobial activity of flavonoids. Int. J. Antimicrob. Agents 2005, 26, 343-356. [CrossRef]

106. Li, D.; Chen, G.; Ma, B.; Zhong, C.; He, N. Metabolic Profiling and Transcriptome Analysis of Mulberry Leaves Provide Insights into Flavonoid Biosynthesis. J. Agric. Food Chem. 2020, 68, 1494-1504. [CrossRef] [PubMed]

107. Li, H.; Li, D.; Yang, Z.; Zeng, Q.; Luo, Y.; He, N. Flavones Produced by Mulberry Flavone Synthase Type I Constitute a Defense Line against the Ultraviolet-B Stress. Plants 2020, 9, 215. [CrossRef] [PubMed]

108. Day, A.J.; Bao, Y.; Morgan, M.R.; Williamson, G. Conjugation position of quercetin glucuronides and effect on biological activity. Free Radic. Biol. Med. 2000, 29, 1234-1243. [CrossRef]

109. Dueñas, M.; Surco-Laos, F.; González-Manzano, S.; González-Paramás, A.M.; Santos-Buelga, C. Antioxidant properties of major metabolites of quercetin. Eur. Food Res. Technol. 2011, 232, 103-111. [CrossRef] 
110. Chao, P.-Y.; Lin, S.-Y.; Lin, K.-H.; Liu, Y.-F.; Hsu, J.-I.; Yang, C.-M.; Lai, J.-Y. Antioxidant activity in extracts of 27 indigenous Taiwanese vegetables. Nutrtion 2014, 6, 2115-2130. [CrossRef]

111. Yang, J.; Guo, J.; Yuan, J. In vitro antioxidant properties of rutin. LWT-Food Sci. Technol. 2008, 41, 1060-1066. [CrossRef]

112. Jiménez-Aliaga, K.; Bermejo-Bescós, P.; Benedí, J.; Martín-Aragón, S. Quercetin and rutin exhibit antiamyloidogenic and fibril-disaggregating effects in vitro and potent antioxidant activity in APPswe cells. Life Sci. 2011, 89, 939-945. [CrossRef] [PubMed]

113. Fang, X.-K.; Gao, J.; Zhu, D.-N. Kaempferol and quercetin isolated from Euonymus alatus improve glucose uptake of 3T3-L1 cells without adipogenesis activity. Life Sci. 2008, 82, 615-622. [CrossRef]

114. Lin, M.-J.; Chang, S.-C.; Jea, Y.-S.; Liao, J.-W.; Fan, Y.-K.; Lee, T.-T. In vitro antioxidant capability and performance assessment of White Roman goose supplemented with dried Toona sinensis. J. Appl. Anim. Res. 2016, 44, 395-402. [CrossRef]

115. Hassan, W.; Rongyin, G.; Daoud, A.; Ding, L.; Wang, L.; Liu, J.; Shang, J. Reduced oxidative stress contributes to the lipid lowering effects of isoquercitrin in free fatty acids induced hepatocytes. Oxid. Med. Cell Longev. 2014, 2014. [CrossRef]

116. Valentová, K.; Vrba, J.; Bancířová, M.; Ulrichová, J.; Křen, V. Isoquercitrin: Pharmacology, toxicology, and metabolism. Food Chem. Toxicol. 2014, 68, 267-282. [CrossRef]

117. Zhou, X.; Wang, F.; Zhou, R.; Song, X.; Xie, M. Apigenin: A current review on its beneficial biological activities. J. Food Biochem. 2017, 41, e12376. [CrossRef]

118. Tsalkidou, E.G.; Tsaroucha, A.K.; Chatzaki, E.; Lambropoulou, M.; Papachristou, F.; Trypsianis, G.; Pitiakoudis, M.; Vaos, G.; Simopoulos, C. The effects of apigenin on the expression of Fas/FasL apoptotic pathway in warm liver ischemia-reperfusion injury in rats. BioMed Res. Int. 2014, 2014. [CrossRef]

119. López-Lázaro, M. Distribution and biological activities of the flavonoid luteolin. Mini Rev. Med. Chem. 2009, 9, 31-59. [CrossRef] [PubMed]

120. Xagorari, A.; Papapetropoulos, A.; Mauromatis, A.; Economou, M.; Fotsis, T.; Roussos, C. Luteolin inhibits an endotoxin-stimulated phosphorylation cascade and proinflammatory cytokine production in macrophages. J. Pharmacol. Exp. Ther. 2001, 296, 181-187. [PubMed]

121. Francisco, V.; Figueirinha, A.; Costa, G.; Liberal, J.; Lopes, M.C.; García-Rodríguez, C.; Geraldes, C.F.; Cruz, M.T.; Batista, M.T. Chemical characterization and anti-inflammatory activity of luteolin glycosides isolated from lemongrass. J. Funct. Foods 2014, 10, 436-443. [CrossRef]

122. Riaz, A.; Rasul, A.; Hussain, G.; Zahoor, M.K.; Jabeen, F.; Subhani, Z.; Younis, T.; Ali, M.; Sarfraz, I.; Selamoglu, Z. Astragalin: A bioactive phytochemical with potential therapeutic activities. Adv. Pharmacol. Sci. 2018. [CrossRef]

123. Qu, D.; Han, J.; Ren, H.; Yang, W.; Zhang, X.; Zheng, Q.; Wang, D. Cardioprotective effects of astragalin against myocardial ischemia/reperfusion injury in isolated rat heart. Oxid. Med. Cell Longev. 2016. [CrossRef] [PubMed]

124. Olagaray, K.; Bradford, B. Plant flavonoids to improve productivity of ruminants-A review. Anim. Feed Sci. Technol. 2019, 251, 21-36. [CrossRef]

125. Berger, L.; Wein, S.; Blank, R.; Metges, C.; Wolffram, S. Bioavailability of the flavonol quercetin in cows after intraruminal application of quercetin aglycone and rutin. J. Dairy Sci. 2012, 95, 5047-5055. [CrossRef]

126. Wein, S.; Beyer, B.; Zimmermann, B.F.; Blank, R.H.; Wolffram, S. Bioavailability of quercetin from onion extracts after intraruminal application in cows. J. Agric. Food Chem. 2018, 66, 10188-10192. [CrossRef]

127. Cermak, R.; Landgraf, S.; Wolffram, S. The bioavailability of quercetin in pigs depends on the glycoside moiety and on dietary factors. J. Nutr. 2003, 133, 2802-2807. [CrossRef]

128. Wein, S.; Wolffram, S. Oral bioavailability of quercetin in horses. J. Equine Vet. Sci. 2013, 33, 441-445. [CrossRef]

129. Cheng, K.-J.; Jones, G.; Simpson, F.; Bryant, M. Isolation and identification of rumen bacteria capable of anaerobic rutin degradation. Can. J. Microbiol. 1969, 15, 1365-1371. [CrossRef]

130. Krishnamurty, H.; Cheng, K.-J.; Jones, G.; Simpson, F.; Watkin, J. Identification of products produced by the anaerobic degradation of rutin and related flavonoids by Butyrivibrio sp. C3. Can. J. Microbiol. 1970, 16, 759-767. [CrossRef]

131. Labib, S.; Erb, A.; Kraus, M.; Wickert, T.; Richling, E. The pig caecum model: A suitable tool to study the intestinal metabolism of flavonoids. Mol. Nutr. Food Res. 2004, 48, 326-332. [CrossRef] 
132. Lin, Y.-T.; Hsiu, S.-L.; Hou, Y.-C.; Chen, H.-Y.; Chao, P.-D.L. Degradation of flavonoid aglycones by rabbit, rat and human fecal flora. Biol. Pharm. Bull. 2003, 26, 747-751. [CrossRef]

133. Aura, A.-M.; O’leary, K.; Williamson, G.; Ojala, M.; Bailey, M.; Puupponen-Pimiä, R.; Nuutila, A.-M.; Oksman-Caldentey, K.-M.; Poutanen, K. Quercetin derivatives are deconjugated and converted to hydroxyphenylacetic acids but not methylated by human fecal flora in vitro. J. Agric. Food Chem. 2002, 50, 1725-1730. [CrossRef]

134. Rechner, A.R.; Smith, M.A.; Kuhnle, G.; Gibson, G.R.; Debnam, E.S.; Srai, S.K.S.; Moore, K.P.; Rice-Evans, C.A. Colonic metabolism of dietary polyphenols: Influence of structure on microbial fermentation products. Free Radic. Biol. Med. 2004, 36, 212-225. [CrossRef]

135. Maciej, J. Oral Bioavailability of Flavonoids and Their Effects on the Metabolic and Antioxidative Status in Neonatal Calves. Ph.D. Thesis, Christian-Albrechts Universität Kiel, Kiel, Germany, 2015.

136. Drackley, J.K. Calf Nutr.ition from birth to breeding. Vet. Clin. North. Am. Small Anim. Prac. 2008, $24,55-86$. [CrossRef]

137. Guilloteau, P.; Zabielski, R.; Blum, J. Gastrointestinal tract and digestion in the young ruminant: Ontogenesis, adaptations, consequences and manipulations. J. Physiol. Pharmacol. 2009, 60, 37-46. [PubMed]

138. Heinrichs, A.; Jones, C. Feeding the newborn calf. In College of Agricultural Sciences, Agricultural Research, and Cooperative Extension; Pennsylvania State University: University Park, PA, USA, 2003.

139. Salinas-Chavira, J.; Castillo-Martínez, O.; Ramirez-Bribiesca, J.E.; Mellado, M. Effect of increasing levels of white mulberry leaves (Morus alba) on ruminal dry matter degradability in lambs. Trop. Anim. Health Prod. 2011, 43, 995-999. [CrossRef] [PubMed]

140. Yulistiani, D.; Jelan, Z.; Liang, J.; Yaakub, H.; Abdullah, N. Effects of supplementation of mulberry (Morus alba) foliage and urea-rice bran as fermentable energy and protein sources in sheep fed urea-treated rice straw based diet. Asian-Australas J. Anim. Sci. 2015, 28, 494. [CrossRef]

141. Rieu, F.; Fonty, G.; Gaillard, B.; Gouet, P. Electron microscopy study of the bacteria adherent to the rumen wall in young conventional lambs. Can. J. Microbiol. 1990, 36, 140-144. [CrossRef]

142. Steele, M.A.; Penner, G.B.; Chaucheyras-Durand, F. Development and physiology of the rumen and the lower gut: Targets for improving gut health. J. Dairy Sci. 2016, 99, 4955-4966. [CrossRef]

143. Yang, C.; Diao, Q.; Qu, P.; Si, B.; Ma, J.; Zhou, Y.; Tu, Y. Effects of Candida tropicalis and mulberry leaf flavonoids on Nutr.ient metabolism and rumen fermentation in calves. J. Anim. Nutr. 2016, 28, 224-234.

144. Zhang, L.; PB, Q.; CT, Y. Effects of flavonoids from mulberry leaves and candida tropicalis on performance and Nutr.ient digestibility in calves. Kafkas Üniversitesi Vet. Fakültesi Derg. 2017, 23, 473-479.

145. Kong, L.; Yang, C.; Dong, L.; Diao, Q.; Si, B.; Ma, J.; Tu, Y. Rumen Fermentation Characteristics in Pre-and Post-Weaning Calves upon Feeding with Mulberry Leaf Flavonoids and Candida tropicalis Individually or in Combination as a Supplement. Animal 2019, 9, 990. [CrossRef]

146. Gonzales, G.B.; Van Camp, J.; Smagghe, G.; Raes, K.; Mackie, A. Flavonoid-gastrointestinal mucus interaction and its potential role in regulating flavonoid bioavailability and mucosal biophysical properties. Food Res. Int. 2016, 88, 342-347. [CrossRef]

147. Bi, Y.; Yang, C.; Diao, Q.; Tu, Y. Effects of dietary supplementation with two alternatives to antibiotics on intestinal microbiota of preweaned calves challenged with Escherichia coli K99. Sci. Rep. 2017, 7, 1-12. [CrossRef]

148. Wang, Y.; Shen, Q.; Zhong, S.; Chen, Y.; Yang, Y. Comparison of Rumen Microbiota and Serum Biochemical Indices in White Cashmere Goats Fed Ensiled or Sun-Dried Mulberry Leaves. Microorganisms 2020, 8, 981. [CrossRef]

149. Mansuri, M.L.; Parihar, P.; Solanki, I.; Parihar, M.S. Flavonoids in modulation of cell survival signalling pathways. Genes Nutr. 2014, 9, 400. [CrossRef]

150. Arjmandi, B.; Khalil, D.; Hollis, B. Ipriflavone, a synthetic phytoestrogen, enhances intestinal calcium transport in vitro. Calcif. Tissue Int. 2000, 67, 225-229. [CrossRef]

151. Zafar, T.A.; Weaver, C.M.; Jones, K.; Moore, D.R.; Barnes, S. Inulin effects on bioavailability of soy isoflavones and their calcium absorption enhancing ability. J. Agric. Food Chem. 2004, 52, 2827-2831. [CrossRef]

152. Li, M.; Hassan, F.; Tang, Z.; Peng, L.; Liang, X.; Li, L.; Peng, K.; Xie, F.; Yang, C. Mulberry leaf flavonoids improve milk production, antioxidant and metabolic status in buffaloes during summer season. Front. Vet. Sci. 2020, 7, 599. [CrossRef] 
153. Miksicek, R.J. Commonly occurring plant flavonoids have estrogenic activity. Mol. Pharmacol. 1993, 44, $37-43$.

154. Zand, R.S.R.; Jenkins, D.J.; Diamandis, E.P. Steroid hormone activity of flavonoids and related compounds. Breast Cancer Res. Treat. 2000, 62, 35-49. [CrossRef] [PubMed]

155. Ferguson, L.R. Role of plant polyphenols in genomic stability. Mutat Res.-Fund Mol. M 2001, 475, 89-111. [CrossRef]

156. Stoldt, A.-K.; Derno, M.; Nürnberg, G.; Weitzel, J.M.; Otten, W.; Starke, A.; Wolffram, S.; Metges, C.C. Effects of a 6-wk intraduodenal supplementation with quercetin on energy metabolism and indicators of liver damage in periparturient dairy cows. J. Dairy Sci. 2015, 98, 4509-4520. [CrossRef] [PubMed]

157. Kehrli, M.; Neill, J.; Burvenich, C.; Goff, J.; Lippolis, J.; Reinhardt, T.; Nonnecke, B. Energy and protein effects on the immune system. In Ruminant Physiology. Digestion, Metabolism and Impact of Nutrition on Gene Expression, Immunology and Stress; Wageningen Academic Publishers: Wageningen, The Netherlands, 2006; pp. $455-471$.

158. Tan, N.; Wanapat, M.; Uriyapongson, S.; Cherdthong, A.; Pilajun, R. Enhancing mulberry leaf meal with urea by pelleting to improve rumen fermentation in cattle. Asian-Australas J. Anim. Sci. 2012, 25, 452. [CrossRef]

159. Bakshi, M.; Wadhwa, M. Tree leaves as complete feed for goat bucks. Small Rumin. Res. 2007, 69, 74-78. [CrossRef]

160. Anbarasu, C.; Dutta, N.; Sharma, K.; Rawat, M. Response of goats to partial replacement of dietary protein by a leaf meal mixture containing Leucaena leucocephala, Morus alba and Tectona grandis. Small Rumin. Res. 2004, 51, 47-56. [CrossRef]

161. Ma, T.; Chen, D.D.; Tu, Y.; Zhang, N.F.; Si, B.W.; Diao, Q.Y. Dietary supplementation with mulberry leaf flavonoids inhibits methanogenesis in sheep. Anim. Sci. J. 2017, 88, 72-78. [CrossRef]

162. Li, Y.; Meng, Q.; Zhou, B.; Zhou, Z. Effect of ensiled mulberry leaves and sun-dried mulberry fruit pomace on the fecal bacterial community composition in finishing steers. BMC Microbiol. 2017, 17, 97. [CrossRef]

163. Niu, Y.; Meng, Q.; Li, S.; Ren, L.; Zhou, B.; Schonewille, T.; Zhou, Z. Effects of diets supplemented with ensiled mulberry leaves and sun-dried mulberry fruit Pomace on the Ruminal bacterial and Archaeal community composition of finishing steers. PLoS ONE 2016, 11, e0156836. [CrossRef]

164. Huyen, N.; Wanapat, M.; Navanukraw, C. Effect of mulberry leaf pellet (MUP) supplementation on rumen fermentation and Nutr.ient digestibility in beef cattle fed on rice straw-based diets. Anim. Feed Sci. Technol. 2012, 175, 8-15. [CrossRef]

165. Yaghoubi, M.; Gh, G.; Satari, R. Antimicrobial activity of Iranian propolis and its chemical composition. DARU J. Pharml. Sci. 2007, 15, 45-48.

166. Santas, J.; Almajano, M.P.; Carbó, R. Antimicrobial and antioxidant activity of crude onion (Allium cepa, L.) extracts. Int. J. Food Sci. Technol. 2010, 45, 403-409. [CrossRef]

167. Sinz, S.; Kunz, C.; Liesegang, A.; Braun, U.; Marquardt, S.; Soliva, C.R.; Kreuzer, M. In Vitro bioactivity of various pure flavonoids in ruminal fermentation, with special reference to methane formation. Czech J. Anim. Sci. 2018, 63, 293-304.

168. Cui, H.; Lu, T.; Wang, M.; Zou, X.; Zhang, Y.; Yang, X.; Dong, Y.; Zhou, H. Flavonoids from Morus alba L. leaves: Optimization of extraction by response surface methodology and comprehensive evaluation of their antioxidant, antimicrobial, and inhibition of $\alpha$-amylase activities through analytical hierarchy process. Molecules 2019, 24, 2398. [CrossRef]

169. Mirzoeva, O.; Grishanin, R.; Calder, P. Antimicrobial action of propolis and some of its components: The effects on growth, membrane potential and motility of bacteria. Microbiol. Res. 1997, 152, 239-246. [CrossRef]

170. Oskoueian, E.; Abdullah, N.; Oskoueian, A. Effects of flavonoids on rumen fermentation activity, methane production, and microbial population. BioMed Res. Int. 2013, 152, 239-246. [CrossRef]

171. AL-Bayati, M.; Hassan, A. Effects of in vitro supplementation of mulberry leaf flavonoids on microbial flora, methanogenesis and fermentative products in rumen fluid of sheep. J. Res. Ecol. 2018, 6, 2067-2077.

172. Winter, J.; Moore, L.; Dowell, V.; Bokkenheuser, V. C-ring cleavage of flavonoids by human intestinal bacteria. Appl. Environ. Microbiol. 1989, 55, 1203-1208. [CrossRef]

173. Schneider, H.; Schwiertz, A.; Collins, M.D.; Blaut, M. Anaerobic transformation of quercetin-3-glucoside by bacteria from the human intestinal tract. Arch. Microbiol. 1999, 171, 81-91. [CrossRef] 
174. Stack, R.J.; Hungate, R.E.; Opsahl, W.P. Phenylacetic acid stimulation of cellulose digestion by Ruminococcus albus 8. Appl. Environ. Microbiol. 1983, 46, 539-544. [CrossRef]

175. Morrison, M.; Mackie, R.I.; Kistner, A. 3-Phenylpropanoic acid improves the affinity of Ruminococcus albus for cellulose in continuous culture. Appl. Environ. Microbiol. 1990, 56, 3220-3222. [CrossRef] [PubMed]

176. Doran, M.; Laca, E.; Sainz, R. Total tract and rumen digestibility of mulberry foliage (Morus alba), alfalfa hay and oat hay in sheep. Anim. Feed Sci. Technol. 2007, 138, 239-253. [CrossRef]

177. Venkatesh Kumar, R.; Gautam, C.; Shobha, N.; Lingappa, R.S. Use of mulberry leaves as supplementary food in cow and goat to improve milk production. Int. J. Appl. Res. 2015, 1, 81-84.

178. Apel, K.; Hirt, H. Reactive oxygen species: Metabolism, oxidative stress, and signal transduction. Annu. Rev. Plant. Biol. 2004, 55, 373-399. [CrossRef]

179. Fandy, T.E.; Jiemjit, A.; Thakar, M.; Rhoden, P.; Suarez, L.; Gore, S.D. Decitabine induces delayed reactive oxygen species (ROS) accumulation in leukemia cells and induces the expression of ROS generating enzymes. Clin. Cancer Res. 2014, 20, 1249-1258. [CrossRef]

180. Tanaka, M.; Kamiya, Y.; Kamiya, M.; Nakai, Y. Effect of high environmental temperatures on ascorbic acid, sulfhydryl residue and oxidized lipid concentrations in plasma of dairy cows. Anim. Sci. J. 2007, 78, 301-306. [CrossRef]

181. Enríquez, D.; Hötzel, M.J.; Ungerfeld, R. Minimising the stress of weaning of beef calves: A review. Acta Vet. Scand. 2011, 53, 1-8. [CrossRef]

182. Antunes, F.; Han, D.; Cadenas, E. Relative contributions of heart mitochondria glutathione peroxidase and catalase to $\mathrm{H}_{2} \mathrm{O}_{2}$ detoxification in in vivo conditions. Free Radic. Biol. Med. 2002, 33, 1260-1267. [CrossRef]

183. Fukai, T.; Ushio-Fukai, M. Superoxide dismutases: Role in redox signaling, vascular function, and diseases. Antioxid. Redox Signal. 2011, 15, 1583-1606. [CrossRef]

184. Kaya, E.; Ozgok, Y.; Zor, M.; Eken, A.; Bedir, S.; Erdem, O.; Ebiloglu, T.; Ergin, G. Oxidative stress parameters in patients with prostate cancer, benign prostatic hyperplasia and asymptomatic inflammatory prostatitis: A prospective controlled study. Adv. Clin. Exp. Med. 2017, 26, 1095-1099. [CrossRef]

185. Kähkönen, M.P.; Hopia, A.I.; Vuorela, H.J.; Rauha, J.-P.; Pihlaja, K.; Kujala, T.S.; Heinonen, M. Antioxidant activity of plant extracts containing phenolic compounds. J. Agric. Food Chem. 1999, 47, 3954-3962. [CrossRef] [PubMed]

186. Jiang, Y.; Piao, H.; Li, G. Study on antioxidant activity of constituents from mulberry leaf. J. Chin. Med. Mater. 2008, 31, 519.

187. Kim, G.N.; Jang, H.D. Flavonol content in the water extract of the mulberry (Morus alba L.) leaf and their antioxidant capacities. J. Food Sci. 2011, 76, C869-C873. [CrossRef] [PubMed]

188. Xiaofeng, Y.; Shuang, Z.; Li, Z.; Dan, W.; Xiaoman, F.; Zhen, O. Effect of frost on flavonol glycosides accumulation and antioxidant activities of mulberry (Morus alba L.) leaves. Pharmacogn. Mag. 2019, 15, 466.

189. Halliwell, B.; Chirico, S. Lipid peroxidation: Its mechanism, measurement, and significance. Am. J. Clin. Nutr. 1993, 57, 715S-725S. [CrossRef]

190. Nerland, D.E. The antioxidant/electrophile response element motif. Drug Metab. Rev. 2007, 39, $235-248$. [CrossRef]

191. Oyagbemi, A.A.; Omobowale, T.O.; Ola-Davies, O.E.; Asenuga, E.R.; Ajibade, T.O.; Adejumobi, O.A.; Arojojoye, O.A.; Afolabi, J.M.; Ogunpolu, B.S.; Falayi, O.O. Quercetin attenuates hypertension induced by sodium fluoride via reduction in oxidative stress and modulation of HSP 70/ERK/PPAR $\gamma$ signaling pathways. Biofactors 2018, 44, 465-479. [CrossRef]

192. Liao, B.-Y.; Zhu, D.-Y.; Thakur, K.; Li, L.; Zhang, J.-G.; Wei, Z.-J. Thermal and antioxidant properties of polysaccharides sequentially extracted from mulberry leaves (Morus alba L.). Molecules 2017, $22,2271$. [CrossRef]

Publisher's Note: MDPI stays neutral with regard to jurisdictional claims in published maps and institutional affiliations. 